\title{
Somewhere beyond the sea: Human cranial remains from the Lesser Sunda Islands (Alor Island, Indonesia) provide insights on Late Pleistocene peopling of Island Southeast Asia
}

07 Sofía C. Samper Carro a, b, c, *, Felicity Gilbert ${ }^{\mathrm{b}}$, David Bulbeck ${ }^{\text {a }}$, Sue O'Connor ${ }^{\text {a, d }}$, Julien Louys $^{\mathrm{e}}$, Nigel Spooner ${ }^{\mathrm{f}, \mathrm{g}}$, Danielle Questiaux ${ }^{\mathrm{f}}$, Lee Arnold ${ }^{\mathrm{f}}$, Gilbert J. Price ${ }^{\mathrm{h}}$, Rachel Wood ${ }^{\mathrm{i}}$, Mahirta ${ }^{\mathrm{j}}$

${ }^{a}$ Archaeology and Natural History, School of Culture, History and Language, College of Asia and the Pacific, Australian National University, Canberra, 2601, Australia

b School of Archaeology and Anthropology, College of Arts and Social Sciences, Australian National University, Canberra, 2601, Australia

${ }^{c}$ Centre d'Estudis del Patrimoni Arqueologic de la Prehistòria, Facultat de Lletres-Edifici B, Universitat Autònoma de Barcelona, 08193, Bellaterra, Spain

${ }^{\mathrm{d}}$ ARC Centre of Excellence for Australian Biodiversity and Heritage, Australian National University, Canberra, 2601, Australia

e Australian Research Centre of Human Evolution (ARCHE), Environmental Futures Research Institute, Griffith University, Nathan, 4111, Australia

${ }^{\mathrm{f}}$ Institute for Photonics and Advanced Sensing \& School of Physical Sciences, University of Adelaide, SA, 5005, Australia

gefence Science and Technology Group, PO Box 1500, Edinburgh, SA, 5111, UK

${ }^{\mathrm{h}}$ School of Earth and Environmental Sciences, The University of Queensland, Brisbane, 4072, Australia

${ }^{i}$ Earth Chemistry, Research School of Earth Sciences, Australian National University, Canberra, 2601, Australia

j Jurusan Arkeologi, Fakultas Ilmu Budaya, Universitas Gadja Madja, Bulaksumur, Yogjakarta, 55281, Indonesia

\section{A R T I C L E I N F O}

Article history:

Received 22 November 2018

Accepted 6 July 2019

Available online $\mathrm{xxx}$

\section{Keywords:}

Lesser Sunda Islands

Anatomically modern humans

Late Pleistocene

Indonesia

Human migration

Craniometrics

\begin{abstract}
A B S T R A C T
The migration of anatomically modern humans (AMH) from Africa to every inhabitable continent included their dispersal through Island Southeast Asia (ISEA) to Australia. Significantly, this involved overwater dispersal through the Lesser Sunda Islands between Sunda (continental Southeast Asia) and Sahul (Australia and New Guinea). However, the timing and direction of this movement is still debated. Here, we report on human skeletal material recovered from excavations at two rockshelters, known locally as Tron Bon Lei, on Alor Island, Indonesia. The remains, dated to the Late Pleistocene, are the first anatomically modern human remains recovered in Wallacea dated to this period and are associated with cultural material demonstrating intentional burial. The human remains from Tron Bon Lei represent a population osteometrically distinct from Late Pleistocene Sunda and Sahul AMH. Instead, morphometrically, they appear more similar to Holocene populations in the Lesser Sundas. Thus, they may represent the remains of a population originally from Sunda whose Lesser Sunda Island descendants survived into the Holocene.
\end{abstract}

๑) 2019 Elsevier Ltd. All rights reserved.

\section{Introduction}

The Late Pleistocene migration of anatomically modern humans $(\mathrm{AMH})$ from Africa to mainland Southeast Asia and into Australia is of great paleoanthropological interest. Current migration models, based on archaeological material and morphological and genetic analyses of paleoanthropological remains, indicate multiple AMH dispersal events. These followed diverse migratory pathways from

\footnotetext{
* Corresponding author.

E-mail address: sofia.samper@anu.edu.au (S.C. Samper Carro).
}

East Africa into the Levant and/or the Arabian Peninsula, and finally Asia, and involved genetic admixture with previously established archaic hominins (e.g., Stoneking and Krause, 2011; Reyes-Centeno et al., 2014; Bae et al., 2017; Martinón-Torres et al., 2017; Sikora, 2017; Groucutt et al., 2018; Hershkovitz et al., 2018). The redating of the Liang Bua stratigraphy containing Homo floresiensis in Flores (Sutikna et al., 2016, 2018), substantive dating of the cave context of Homo sapiens fossil material in Sumatra at 73,000-63,000 BP (Westaway et al., 2017), and new sites with human Pleistocene deposits in several Wallacean islands have sparked renewed interest in this region. 
In addition to determining the timing of the first arrival of AMH and modeling the migratory routes from Sunda (mainland Southeast Asia, Sumatra, Java and Borneo) to Sahul (Australia, Papua New Guinea and Aru Island), the impact of the Last Glacial Maximum (LGM; 26-15 ka) has generated significant attention in Island Southeast Asia (ISEA). The LGM led to a sea level drop of up to $135 \mathrm{~m}$. Following the LGM, the region saw repeated instances of rapid sea level changes alternating with periods of relatively stable sea level, until current sea level was reached ca. 7 ka (Lambeck et al., 2014).

The LGM is associated with climatic and environmental changes that would have affected insular biota, and consequently impacting human subsistence (O'Connor and Aplin, 2007; O'Connor et al., 2017a). Lower sea levels would have increased inter-island visibility and changes in resource availability (Kealy et al., 2017; O'Connor et al., 2017a). In tandem, these factors might have motivated human dispersal into neighboring islands. The Pleistocene-Holocene transition, when sea levels rose rapidly after the Younger Dryas, is associated with major changes in human settlement and mobility, shifts in material culture, and the emergence of burial traditions in East and Southeast Asia (Piper, 2016).

Two opposing models have been proposed to explain the population history of East and Southeast Asia during the Late Pleistocene and Holocene. The first of these, the two-layer hypothesis, is supported by linguistic data and select archaeological and fossil AMH evidence. It applies the name Australo-Melanesian to the initial AMH colonists who occupied the lands from south China and Japan to Australia, and recognizes a subsequent middle Holocene expansion of farming populations from central/northern China that resulted in morphological and genetic similarities of present day North and Southeast Asian populations, excluding Negritos (Chi and Hung, 2010; Matsumura and Oxenham, 2014; Bellwood, 2017; Matsumura et al., 2017). In contrast, the regional continuity model proposes evolutionary continuity for Northeast Asian, Southeast Asian and Australo-Melanesian population complexes, with negligible genetic interaction between these population complexes during the Holocene (Turner, 1990; Capelli et al., 2001; Pietrusewsky, 2010). Morphological changes shown by Southeast Asian AMH fossil remains during the Holocene are attributed to climatic amelioration (Storm, 1995).

In between these contrasting models are studies that accept the case for a middle Holocene farmer expansion, as proposed by the two-layer hypothesis, but in the context of other population dispersals. These include multiple migrations from Northeast to Southeast Asia as early as the Late Pleistocene, based on attributes shown by the Wajak skull in Java (Jacob, 1967), the Deep Skull from Niah in Borneo (Curnoe et al., 2016), and/or major population dispersals within ISEA and Taiwan triggered by sea level changes at the Pleistocene-Holocene transition (e.g., Tabbada et al., 2010; Bulbeck, 2015; Brandão et al., 2016; Hudjashov et al., 2017). A recent study that included aDNA from Holocene fossils between
Sumatra and southern China inferred multiple migrations across this region before, during and after the middle Holocene (McColl et al., 2018).

The islands of southeastern Wallacea (Lesser Sunda Islands) are geographically peripheral to the central points of dispute above. Archaeological evidence of AMH in the Lesser Sunda Islands dates back to at least ca. $40 \mathrm{ka}$ cal BP in Sulawesi and Timor (e.g., Aubert et al., 2014; O'Connor and Bulbeck, 2014; O'Connor et al., 2017a); however, the lack of Pleistocene AMH fossils hinder assessments of the peopling history of these islands. Van der Plas (2007) conducted one of the few studies addressing the population dynamics of the Wallacean Islands. Based on Holocene AMH individuals from Flores, Van der Plas (2007), proposed that the eastward migration of $\mathrm{AMH}$ to Australia involved the colonization of these islands, and the evolution of a population complex that remained distinct even after experiencing some low-level admixture with Asian immigrants during the late Holocene.

The archaeological deposits from Tron Bon Lei (Alor Island, Indonesia) have provided a valuable arena for research into human abilities and migration paths through Wallacea during the Late Pleistocene, including the interval following the LGM (Fig. 1). In 2014, three $1 \times 1 \mathrm{~m}$ test pits were excavated at Tron Bon Lei, in two rockshelters located near the modern village of Lerabain. The excavations yielded large amounts of shellfish, stone artifacts and fish bones. Zooarchaeological assemblages suggest Alor had sparse terrestrial fauna during the Late Pleistocene-early Holocene, mostly comprised of small rodents and reptiles (Samper Carro et al., 2016 2017; O'Connor et al., 2017a,b; Hawkins et al., 2018), although it did host at least one endemic giant rat species (Louys et al., 2018). Based on the large amounts of shellfish and fish remains recovered, human subsistence strategies are characterized as heavily reliant on marine resources whose availability changed due to environmental and sea level changes (Samper Carro et al., 2016, 2017). In association with the vast zooarchaeological assemblages, three human individuals were documented in two of the test pits excavated (Test Pit B and C). One of the individuals was interred with grave goods and associated with two large cobbles covered in ocher (O'Connor et al., 2017b). The other two individuals are comprised of disarticulated skeletal elements, mainly cranial remains, also associated with cobble manuports.

This paper presents new dates and a description of the human cranial remains documented in Tron Bon Lei during the 2014 excavations. We describe the cranial phenotypes and provide a bioskeletal profile. Our observations and craniometric values are compared to osteometric measurements published for other Pleistocene, Holocene and present day AMH remains from Northeast Asia, Southeast Asia, Papua New Guinea and Australia (Fig. 2; Table 1), in order to assess possible phenotypic links to these populations. Our research provides us with the opportunity to reexamine the model proposed by Van der Plas (2007) on the evolution of a distinct population complex in Southeastern Indonesia,

(1)
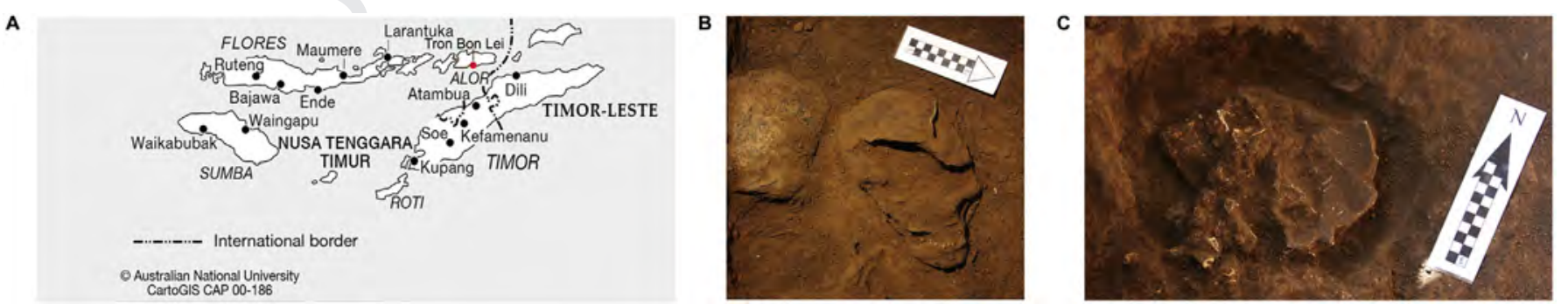

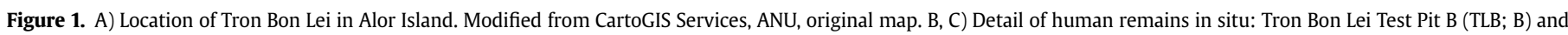
Test Pit C (TLC-1; C). 


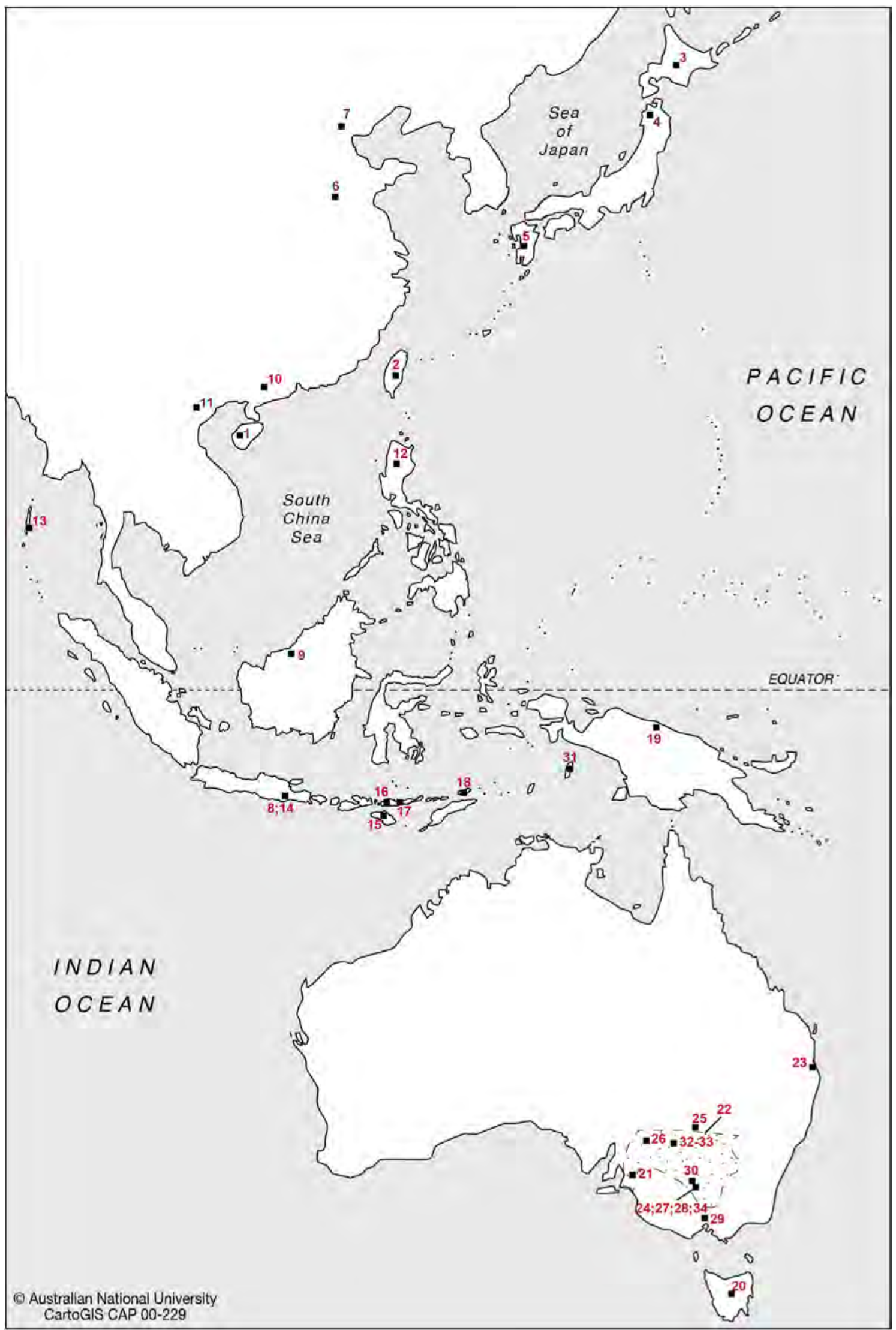

Figure 2. Map with the geographical location of the specimens considered in our craniometric comparison. See Table 1 for number correlation. 
Table 1

List of specimens, including chronology and provenance, considered for the craniometric comparison.

\begin{tabular}{|c|c|c|c|c|c|}
\hline Region & Specimen/site & $\begin{array}{c}\text { Dates/date range } \\
\text { (years BP) }\end{array}$ & Provenance $^{\mathrm{a}}$ & Chronology & References \\
\hline \multirow{13}{*}{$\begin{array}{l}\text { East Asia/SE } \\
\text { Asia/Sunda }\end{array}$} & Hainan & Modern & Haikou city, China (1) & Recent & Howells, 1973, 1989 \\
\hline & China & Modern & China & Recent & Storm, 1995 \\
\hline & Atayal & Modern & Taiwan (2) & Recent & Howells, 1973, 1989 \\
\hline & Ainu & Modern & Japan (3) & Recent & Howells, 1973, 1989 \\
\hline & Hokkaido & Modern & North Japan (4) & Recent & Howells, 1973, 1989 \\
\hline & North Kyushu & Modern & South Japan (5) & Recent & Howells, 1973, 1989 \\
\hline & Anyang & 3200 & China (6) & Holocene & Howells, 1973, 1989 \\
\hline & Upper Cave & $33,000-10,000$ & Northern China (7) & $\begin{array}{l}\text { Late Pleistocene, } \\
\text { Holocene }\end{array}$ & Webb, 1989; Storm, 1995 \\
\hline & Wajak & $>37,400-28,500$ & Java, Indonesia (8) & Late Pleistocene & Storm, 1995 \\
\hline & Ngandong & $>40,000$ & Java, Indonesia (8) & Late Pleistocene & Webb, 1989; Yokoyama et al., 2008 \\
\hline & Deep Skull, Niah Cave & ca. 50,000 & Borneo, Malaysia (9) & Late Pleistocene & Curnoe, et al., 2016 \\
\hline & Liujiang & $140,000-40,000$ & Guanxi Province (10) & Late Pleistocene & Storm, 1995; Shen et al., 2002 \\
\hline & Hang Muoi 1 & ca. $15,000-12,000$ & North Vietnam (11) & Late Pleistocene & Bulbeck et al., 2007 \\
\hline \multirow[t]{9}{*}{ ISEA } & Java & Modern & Java, Indonesia & Recent & Storm, 1995 \\
\hline & Philippines & Modern & Philippines (12) & Recent & Howells, 1973, 1989 \\
\hline & Andaman Island & Modern & Andaman Islands (13) & Recent & Howells, 1973, 1989 \\
\hline & Hoekgrot & ca. 3000 & Java, Indonesia (14) & Holocene & Storm, 1995 \\
\hline & Melolo & ca. 2000 & Sumba, Indonesia (15) & Holocene & Bulbeck, pers. comm.; Bellwood, 2017 \\
\hline & Liang Momer & $7000-4000$ & Flores, Indonesia (16) & Holocene & Storm, 1995, Van der Plas, 2007 \\
\hline & Liang Toge & ca. $7000-4000$ & Flores, Indonesia (17) & Holocene & Jacob, 1967; Storm, 1995; Van der Plas, 2007 \\
\hline & Tron Bon Lei-B & ca. 12,000 & Alor, Indonesia (18) & Late Pleistocene & This paper; O'Connor et al., 2017b \\
\hline & Tron Bon Lei-C & $17,000->7000$ & Alor, Indonesia (18) & Late Pleistocene & This paper \\
\hline \multirow[t]{17}{*}{ Australia/Papua/Sahul } & Papua (several sites) & Modern & Papua New Guinea (19) & Recent & Green, 1990; Storm, 1995 \\
\hline & Tasmania & Modern & Tasmania, Australia (20) & Recent & Howells, 1973, 1989 \\
\hline & Swanport & Modern & SA, Australia (21) & Recent & Brown, 1989 \\
\hline & Australia & Modern & Australia & Recent & Storm, 1995 \\
\hline & Murray Valley & Modern & VIC, Australia (22) & Recent & Brown, 1989; Curnoe et al., 2016 \\
\hline & Broadbeach & Modern & QLD, Australia (23) & Recent & Brown, 1989 \\
\hline & Barham & ca. 5400 & VIC, Australia (24) & Holocene & Brown, 1989 \\
\hline & Mossgiel & ca. 6000 & NSW, Australia (25) & Holocene & Brown, 1989 \\
\hline & Lake Nitchie & ca. 7000 & NSW, Australia (26) & Holocene & Brown, 1989 \\
\hline & Kanalda & ca. 10,000 & Australia (27) & Pleistocene/Holocene & Storm, 1995 \\
\hline & Nacurrie & Unknown & VIC, Australia (28) & Pleistocene/Holocene & Brown, 1989 \\
\hline & Keilor & ca. 12,000 & VIC, Australia (29) & Late Pleistocene & Brown, 1989; Storm, 1995 \\
\hline & Coobool Creek & ca. 14,300 & NSW, Australia (30) & Late Pleistocene & Brown, 1989; Webb, 1989 \\
\hline & Liang Lembudu & $18,000-16,000$ & Aru Island (31) & Late Pleistocene & Bulbeck, 2006 \\
\hline & Willandra Lakes & $20,000-10,000$ & VIC, Australia (32) & Late Pleistocene & Webb, 1989 \\
\hline & Lake Mungo & ca. 40,000 & VIC, Australia (33) & Late Pleistocene & Brown, 1989; Storm, 1995 \\
\hline & Cohuna & Inferred $>10,000$ & VIC, Australia (34) & Late Pleistocene & Brown, 1989 \\
\hline
\end{tabular}

Abbreviations: SA = South Australia; VIC = Victoria; QLD = Queensland; NSW = New South Wales.

${ }^{a}$ Numbers in parentheses relate to numbers in Figure 2, denoting provenance location.

as well as discuss the current archaeological and genetic evidence on the peopling of ISEA.

\section{Materials and methods}

The material described in this manuscript was excavated under an Indonesia Research Visa 315, and following excavation, was on loan to the Archaeology and Natural History Department, in The Australian National University (ANU, Canberra, Australia), where reconstruction and analysis of the remains was conducted. The material has now been returned to Indonesia where it is held in the Archaeology Department at the Universitas Gadjah Mada (UGM, Yogyakarta, Indonesia). The human remains are stored with the archaeological material from Tron Bon Lei. No catalog accession numbers have yet been assigned to the material as it has not been deposited in a museum.

\subsection{Fieldwork procedures}

Excavation of Test Pit B is detailed in Samper Carro et al. (2016, 2017) and O'Connor et al. (2017b). The human remains documented in Test Pit B (TLB) were uncovered ca. $2.1 \mathrm{~m}$ depth and the distribution of human remains continued until $2.26 \mathrm{~m}$ depth in the SE corner. No clear grave was observed, although a change in the stratigraphic context suggest a shallow grave cut from the top layer (Layer 11) and dug into the top of the layer below (Layer 12). Additionally, two large cobbles with ocher were documented, one of them near the south wall and behind the cranium and the second one on the NE corner. The human remains and associated cultural material occurred within an orange-brown silty sand surrounded by a compacted darker brown silty clay (see O'Connor et al., 2017b: Fig. 6).

The documented skeletal elements consisted of a fragmented skull with maxilla and mandible (Fig. 3) and some postcranial bones: both scapulae, some fragments of ribs and vertebrae and a long bone, most likely the humerus, preserving only the diaphysis. The frontal bone and facial part of the cranium were facing north and resting on the left zygomatic. A complete circular fish-hook and a perforated bivalve were documented beneath the chin, while three other circular fish-hooks were found around the mandible and a partial jabbing hook was found under the mandible (see O'Connor et al., 2017b: Fig. 2).

The Test Pit $C$ deposit was relatively shallow, around $70 \mathrm{~cm}$, before reaching bedrock. Layer 2 (the upper layer comprising the top soil) was a compact dark brown sandy silt, while Layer 3 was a slightly lighter brown sandy silt. Both layers are well sorted. Layer 4 


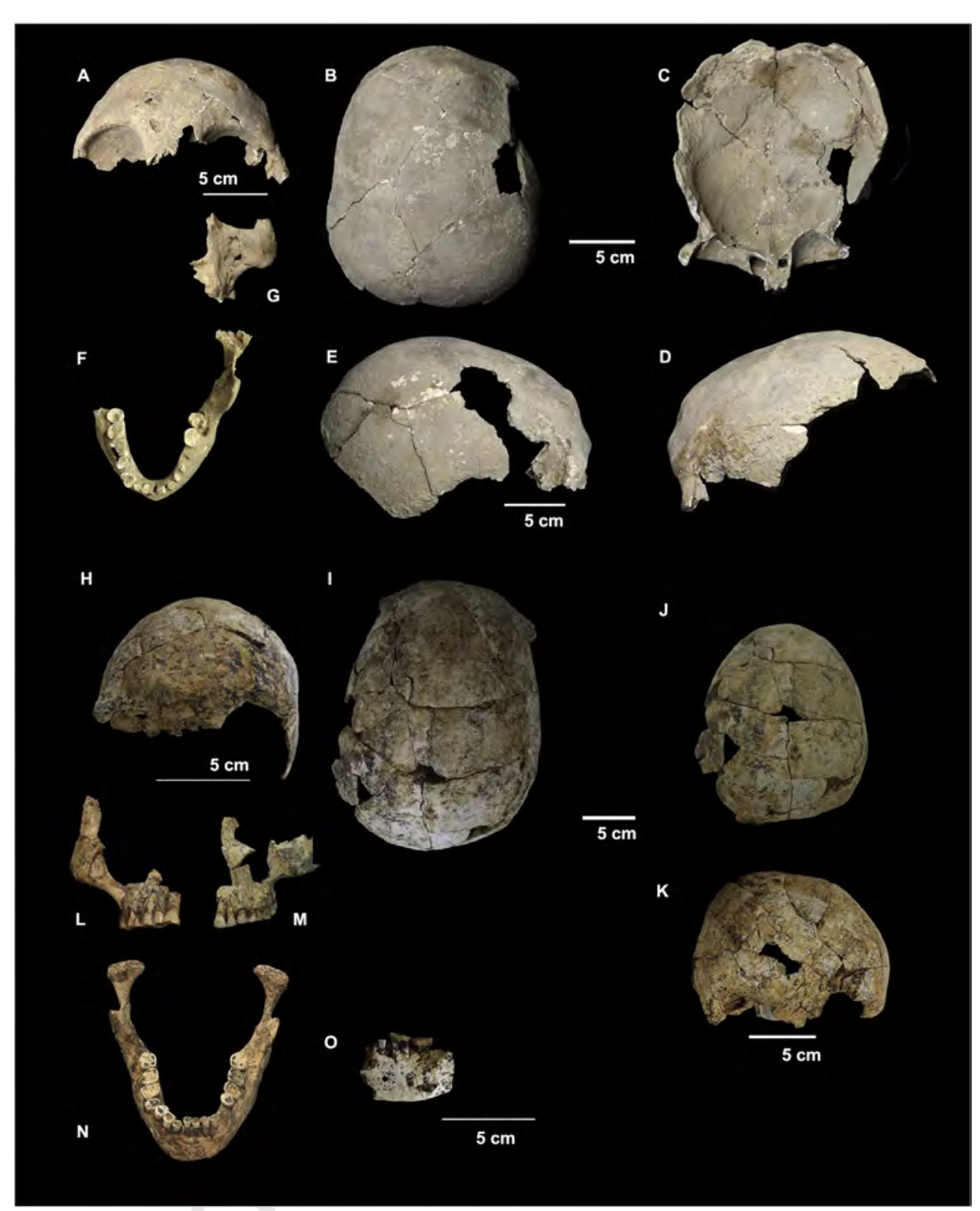

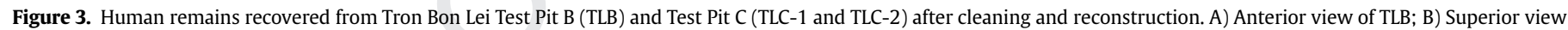

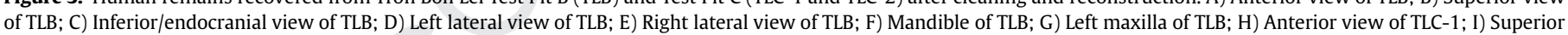

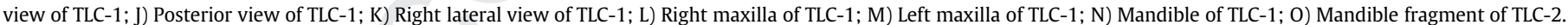

consists of a light brown-orange compact silty clay with large rocks; it is poorly sorted with a gritty texture (Fig. 4). The human remains from Test Pit C (TLC-1) were identified in the bottom layer (Layer 4), and started to appear in spit 11 (ca. depth $55 \mathrm{~cm}$ ) in the center of the southwest quadrant of the pit, around $20 \mathrm{~cm}$ from the south wall and $20 \mathrm{~cm}$ from the west wall. No grave cut from layers above was evident in the sections. The cranial remains were surrounded by large rocks and water-rolled cobbles; the latter are almost certainly manuports brought into the rockshelter from surrounding areas (Fig. 4). TLC-1 comprised the cranium and mandible (Fig. 3), with vertebrae and ribs extending towards the south wall. It is unclear in which the direction the individual was aligned.

The second accumulation of human remains (TLC-2) appeared at the end of spit 11-beginning of spit 12 and was located near the center of the test pit, around $35 \mathrm{~cm}$ from the north wall and $40 \mathrm{~cm}$ from the south wall, and centered relative to both west and east walls (Fig. 4). During fieldwork, these remains were described as containing cranium fragments and a fragment of mandible. More human remains appeared in the spit underneath (spit 13, depth ca. $65 \mathrm{~cm}$ ), which covered the center of the test pit, from the north wall to the south wall, and extended around $20 \mathrm{~cm}$ from the west wall and $40 \mathrm{~cm}$ from the east wall. In general, several fragments and bone elements were scattered through the test pit $\left(1 \mathrm{~m}^{2}\right)$ and distributed among 3 spits ( $15 \mathrm{~cm}$ depth). Due to time constraints, bones that could not be removed during the excavation were left in situ and reburied.

The TLC-1 accumulation comprised an almost complete cranium, mandible, cervical vertebrae, clavicle and some ribs as well as a few hand phalanges and some fragmented metacarpals. TLC-2 

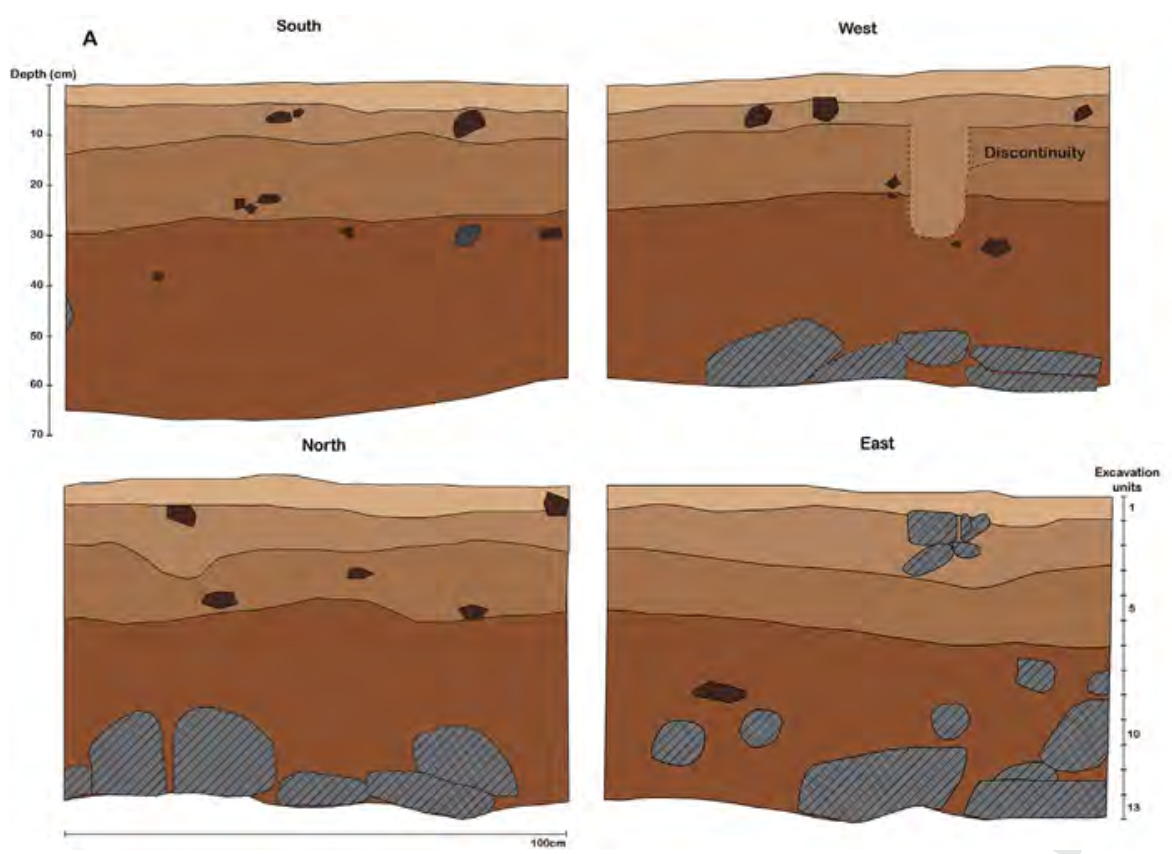

B

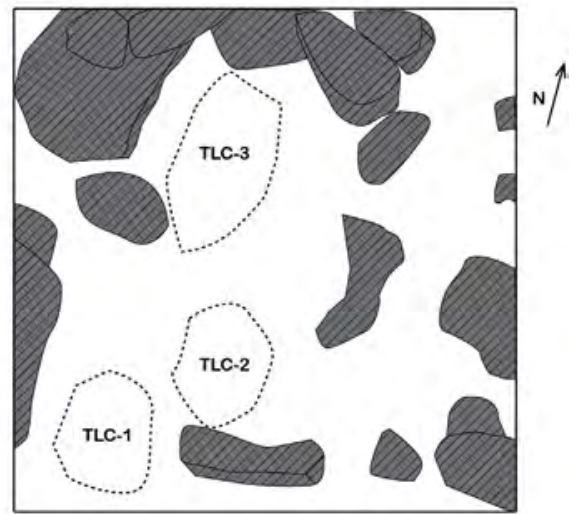

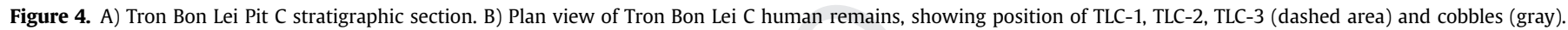

yielded fragments of cranium, including one of the mastoid processes and a fragment of the left mandibular body with the first and second molars in place (Fig. 3). A separate accumulation (TLC-3) consisted of long bones fragments. One of the more complete long bones has been identified as a humerus. A second long bone displays morphological traits consistent with a tibia, although poor preservation and deformation due to postdepositional processes hamper its positive identification. Both long bones are fragmented into sections of variable length, with no preservation of epiphyses.

\subsection{Geochronology}

AMS ${ }^{14} \mathrm{C}$ dating The accelerator mass spectrometry (AMS) ${ }^{14} \mathrm{C}$ dates associated with TLB have been reported in O'Connor et al. (2017b). In this paper, we add the ${ }^{14} \mathrm{C}$ dates obtained for Test Pit $\mathrm{C}$, providing a chronostratigraphy for the TLC-1, TLC- 2 and TLC-3 remains. The methods applied are described in Supplementary Online Material (SOM) S1. All radiocarbon dates have been calibrated against IntCal13 or Marine13 (Reimer et al., 2013) in OxCal 4.3.2. (Bronk Ramsey, 2017).

In order to test the reliability of these context dates, we applied both U-Th and optically stimulated luminescence (OSL) dating methods to the human remains and associated sediments, respectively.

U-Th dating Tooth dentine from two skulls (TLB and TLC-1, from Test Pit B and C, respectively) were targeted for direct U-Th dating. Fresh bone and teeth contain little to no U. However, because $U$ is soluble in water, it commonly migrates into such biological tissues during fossilization. $U$ then decays via a series of intermediate daughter isotopes (including ${ }^{238} \mathrm{U},{ }^{234} \mathrm{U}$, and ${ }^{230} \mathrm{Th}$ ). The U-Th age is calculated by measuring the amount of ${ }^{230} \mathrm{Th}$ relative to the original $\mathrm{U}$. Thus, in most cases, the resulting age is a minimum age for the tissues. In rare cases, $U$ may be leached from a given tooth or bone, leading to age overestimation. However, this can be easily tested for by constructing ${ }^{230} \mathrm{Th}$ age and $U$ concentration profiles through the dated material (Pike et al., 2002), a method adopted in this study following the sampling approach described in Price et al. (2013).
Samples were measured using a Nu Plasma HR multi-collector inductively coupled plasma mass spectrometer at the Radiogenic Isotope Facility, The University of Queensland, Australia, following techniques outlined in Zhou et al. (2011).

OSL dating The sample for OSL analyses and radioisotope assays was collected from the soil preserved inside the TLC-1 skull fragments, wrapped with light-proof aluminum foil wrapping. Dose-rate evaluation was performed using an assay of radioisotope concentrations in the sediment associated with the skull fragments. Uranium, thorium, and potassium concentrations were measured from a dried homogenized split of sediment separated from this material. Analyses were performed by Intertek Genalysis Adelaide, using lithium metaborate/tetraborate fusion and analysis by inductively coupled plasma mass spectrometry (ICPMS) and inductively coupled plasma optical (atomic) emission spectrometry (ICPOES). This required approximately $10 \mathrm{~g}$ of sediment to be sacrificed, and this was the only assay undertaken as there was insufficient untreated sediment remaining following extraction of quartz grains for OSL analysis to enable application of other assay techniques.

In situ gamma ray spectrometry was not undertaken due to the unavailability of a spectrometer at the time of sample collection. However, field observations indicated spatial homogeneity of the sediment body on the relevant scale for soil radioisotope gamma rays, hence validating the use of gamma dose-rate calculated from the ICPMS/ICPOES data. Water content was measured by weighing a split of the raw sediment separated from the skeletal material immediately after removal from the foil packaging, then reweighing after drying overnight at $125{ }^{\circ} \mathrm{C}$. The water content was calculated as \% of dry weight. The cosmic ray contribution was calculated using site location and field data input into the relationships between cosmic ray penetration, sample burial depth, altitude, longitude and latitude as determined by Prescott and Hutton (1994). The environmental radiation dose-rate was calculated using the AGE99 program of Grün (1999). Inputs included the grain diameter, radionuclide activities, water content and the calculated cosmic ray dose-rate. 
Luminescence measurements were performed using a Risø TL/ OSL-DA-20 reader ('R4') in the Prescott Environmental Luminescence Laboratory, School of Physical Sciences, University of Adelaide, Australia. Radiation was applied using a calibrated $1.48 \mathrm{GBq}$ ${ }^{90} \mathrm{Sr} /{ }^{90} \mathrm{Y} \beta$ source. Each single-grain pit position in the $10 \times 10$ array had previously been individually calibrated using precisely-dosed calibration quartz grains in the same grain size range, necessary because the dose-rate delivered to the sample is not uniform across the disc plane. Using the conversion factors obtained, the absorbed dose was calculated (from seconds to $\mathrm{Gy}$ ) for each grain position. Luminescence was stimulated using a green laser beam at up to $50 \mathrm{~W} / \mathrm{cm}^{2}$ beam intensity (wavelength $532 \mathrm{~nm}$ ). Emitted luminescence was detected using an Electron Tubes 9235QB photomultiplier optically filtered by a $7 \mathrm{~mm}$ thick Hoya U 340 filter. Sample preparation procedures and the measurement protocols performed are described in SOM S1.

\subsection{Human remains: reconstruction and analysis}

The laboratory treatment of the remains and virtual reconstruction procedures are described in SOM S1.

Bioskeletal profile Assessing the age and sex of human remains requires the observation and evaluation of a range of traits in a complete skeleton. Unfortunately, in archaeological contexts where the skeletal remains recovered are partial or highly fragmented, the accuracy and precision of the estimation depend on several factors (White and Folkens, 2005). Due to the lack of critical postcranial elements for aging and sexing, such as the pelvic girdle and the epiphyses of long bones, our assessments are provisionally based on the physical traits observed on the skull.

Age estimation was based on two features, dental wear and cranial suture closure. Age estimations from dental wear were obtained by describing the tooth wear in terms of the patterns defined by Lovejoy (1985) and Brothwell (1989). Although dental attrition is affected by several factors, such as diet, tooth wear patterns are considered a reliable indicator of adult age-at-death (Lovejoy, 1985; Richards and Miller, 1991). Cranial suture estimations are based on the system developed at Kent State University, which involves scoring a series of ten cranial sutures for degree of closure, and adding up the scores (Meindl and Lovejoy, 1985). This method overcomes the variability in the timing of the individual sutures' closure. However, this method should never be used in isolation and needs to be corroborated by other available age estimation techniques.

Several researchers have proposed a broad range of viable traits to determine the sex of the skull, whose reliability varies depending on the trait. Our sex estimation for the cranial remains follows Walrath et al.'s (2004) method of weighted cranial characteristics. This method requires evaluation of 10 reliable cranial traits and scores them from -2 (hyperfeminine) to +2 (hypermasculine) and weights the scores regarding their relative importance in determining sex and obtaining a sexualization index (SI). The other method used to estimate sex focuses on the mandible, by assessing mandibular flexure and chin development (Bass, 1995; Loth and Henneberg, 1996). Results from the mandible and cranium were compared and evaluated.

Craniometric analyses Our analysis focuses on measurements and indices that have been recorded for the largest number of comparative specimens and series as possible, avoiding measurements (notably measurements of the mastoid process) affected too markedly by sexual dimorphism. Although the measurements available for this analysis are limited by the high fragmentation of the remains, we focused on measurements traditionally applied to evaluate cranial variations related to ancestry for Pleistocene, Holocene and recent populations (see references in Tables 1 and 2). Table 2 illustrates the different measurements and indices calculated for the TLB and TLC-1 crania. As per the protocol proposed by Ousely and Jantz (2005), where only bifrontal breadth (FMB) is available maximum supraorbital breadth (MSB; used in our analysis) is estimated by adding $6 \mathrm{~mm}$ to the FMB value for females and $10 \mathrm{~mm}$ to the FMB value for males.

Due to the high fragmentation of TLB mandible, we exclude both the TLB and the TLC- 1 mandibles from the osteometric comparisons, as the measurements available from TLB were too few.

\section{Table 2}

Cranial and mandibular measurements and indexes applied in this manuscript.

\begin{tabular}{|c|c|c|c|}
\hline & Abbreviation & Description & Reference \\
\hline \multirow[t]{10}{*}{ Cranial measurements } & GOL & Maximum cranial length & Howells, 1973 \\
\hline & $\mathrm{XCB}$ & Maximum cranial breadth & Howells, 1973 \\
\hline & FMB & Bifrontal breadth & Howells, 1973 \\
\hline & FRC & Frontal chord & Howells, 1973 \\
\hline & MDH & Mastoid height or length & Howells, 1973 \\
\hline & MDB & Mastoid breadth or width & Howells, 1973 \\
\hline & PAC & Parietal chord & Howells, 1973 \\
\hline & WMH & Cheek height & Howells, 1973 \\
\hline & MSB & Maximum supraorbital breadth & Larnach and Macintosh, 1970 \\
\hline & XCB*100/GOL & Cranial index & Howells, 1973 \\
\hline \multirow[t]{13}{*}{ Mandibular measurements } & ML & Mandibular length & Brothwell, 1981 \\
\hline & WI & Bi-condylar breadth & Brothwell, 1981 \\
\hline & $\mathrm{CrH}$ & Coronoid height & Brothwell, 1981 \\
\hline & Che & Corpus height & Brown, 1989 \\
\hline & CTh & Corpus thickness & Brown, 1989 \\
\hline & $\mathrm{SHe}$ & Symphysis height & Brown, 1989 \\
\hline & STh & Symphysis thickness & Brown, 1989 \\
\hline & $\mathrm{RB}$ & Ramus breadth & Brothwell, 1981 \\
\hline & & Height mental foramen & Jacob, 1967 \\
\hline & & Diameter condyloid process & Jacob, 1967 \\
\hline & & Inter- $\mathrm{C}_{1}$ distance & Jacob, 1967 \\
\hline & & Inter- $\mathrm{M}_{1}$ distance & Jacob, 1967 \\
\hline & & Inter- $\mathrm{M}_{3}$ distance & Jacob, 1967 \\
\hline \multirow[t]{4}{*}{ Mandibular indexes } & $\mathrm{WI}^{*} 100 / \mathrm{ML}$ & Mandibular index & Storm, 1995 \\
\hline & $\mathrm{CrH}^{*} 100 / \mathrm{ML}$ & Mandibula length-height index & Storm, 1995 \\
\hline & $\mathrm{ML}+\mathrm{WI}+\mathrm{CrH} / 3$ & Mandibula module & Storm, 1995 \\
\hline & $\mathrm{Che}+\mathrm{CTh}+\mathrm{SHe}+\mathrm{STh}$ & Corpus mandibula module & Storm, 1995 \\
\hline
\end{tabular}


Similarly, even though differences in dental dimensions have been suggested to be related to human dispersal in Wallacea (e.g., Van der Plas, 2007), we do not include dental measurements or the description of non-metric dental traits in this paper. The description of the cranial and mandibular remains and their metrics are included in SOM S2.

The cranial measurements obtained from TLB and TLC-1 were compared with osteometric mean values from Pleistocene, Holocene and recent skulls listed in Table 1 and located in Figure 2. To simplify the comparison between specimens and regions, we have grouped the Pleistocene and Holocene individuals into three geographical groups: Sunda, ISEA and Sahul. Each specimen was included within one of these groups considering the sea level adjusted to their chronology (Lambeck and Chappell, 2001; Lambeck et al., 2014). Therefore, specimens such as the Deep Skull from Niah Cave (Malaysia) or Wajak (Java), dated to the Late Pleistocene, were grouped with the Sunda specimens, while remains from Liang Lembudu (Aru Island), were grouped with the Sahul individuals. Remains from Hoekgrot (Java), dated to the Holocene, were included within the ISEA group, as Java would have been separate from the Sunda shelf ca. 3000 years BP. For recent specimens, we have grouped individuals according to their general geographic provenance: ISEA (Java grouped with the islands to the east), China, Japan, Australia and Papua New Guinea.

Comparisons of measurements involve both size and shape components, of which the size component can dominate if appropriate steps are not followed. Our analysis applies principal components analysis (PCA) to the original measurements (SOM Tables S1 and S2). With biological data, the first principal component (PC1) can be expected to mainly account for size, as would be shown by positive loadings of all of the entered measurements on PC1 (Joliffe, 2002). The other principal components should then reveal shape differences with the removal of the size component, and of these the second principal component (PC2) should be the main shape component. The advantage of this method is that size information is retained, which may be important geographically and chronologically, as well as providing the main shape component after accounting for size differences. PCAs based on Mosimann shape ratios (e.g., Jungers et al., 1995) were not attempted due to the presence of missing data in some of the Pleistocene and Holocene specimens (SOM Tables S1 and S2), which would render the geometric mean and the resulting Mosimann shape variables for those individuals not comparable with those of individuals without missing data. All statistical tests were conducted using the software PAST v. 3.21 (Hammer et al., 2001). Missing values were calculated through iterative imputation. In this method, missing values are initially replaced by their column average. An initial PCA run is then used to compute regression values for the missing data. The procedure is iterated until convergence is achieved (Hammer and Harper, 2006), with the caveat that this method can cause some overestimation of the strength of the components (Ilin and Raiko, 2010).

\section{Results}

\subsection{Geochronology}

AMS ${ }^{14} \mathrm{C}$ dating Table 3 includes the AMS ${ }^{14} \mathrm{C}$ dates on charcoal and mollusk for Test Pits B and C from Tron Bon Lei. The dates associated with TLB (SANU-40125, SANU-41825, SANU-40124) indicate a deposition ca. 11.1-12.5 ka cal BP. These include a date on a shell fish-hook (SANU-41825) buried in association with TLB. For Test Pit $C$, no charcoal or shells in association with the human remains were recovered. Nevertheless, the dates for the Test Pit range from 3.5 to $7.2 \mathrm{ka}$ cal BP (Table 3).
U-Th dating We produced six new dates based on dentine for two teeth, one each from TLB and TLC-1 (Table 4). U concentration in both respective teeth is relatively uniform. The dentine contains only low levels of detrital Th, causing little to no impact on the uncorrected versus corrected ages. ${ }^{230} \mathrm{Th}$ ages are also consistent across the respective teeth. These data strongly suggest that the teeth have not experienced $U$ loss, thus provide reliable minimum ages of ca. $13 \mathrm{ka}$ and $7.7 \mathrm{ka}$ for burials TLB and TLC-1, respectively.

OSL dating The initial analysis of TLC-1 remains, utilizing the central age model (CAM), produced an age of $16.2 \pm 1.0 \mathrm{ka}$. Subsequent fine mixture model (FMM) analysis revealed two components, with two grains comprising a distinct but much younger component (age of approximately $6.8 \pm 2.1 \mathrm{ka}$ ), and a major component containing 25 of the 27 datable grains. Hence, we eliminated the two younger grains from the pooled grain age, and re-analysis of the major component revealed by the FMM modeling gave an age of $17.3 \pm 0.9 \mathrm{ka}$. which we interpret as being the most reliable age estimate for the time of burial of the TLC-1 remains.

\subsection{Description of the remains}

Table 5 summarizes the skeletal elements identified in the TLB and the TLC accumulations, excluding the postcranial elements due to their poor preservation. The cranial and mandibular remains (Fig. 3) are individually described in SOM S2, including observations on the measurements taken (SOM Table S3).

\subsection{Age at death estimate}

All visible sutures (3-6 ectocranial vault) on the calvaria of TLB are completely obliterated, which according to Meindl and Lovejoy (1985) gives a minimum age estimate of 45 years (Table 6). Regarding the dentition, the third molars are fully erupted in both mandible and maxilla and show a high degree of wear. Extreme dental attrition (exposing the pulp cavity) is observed on both sides on the mandibular premolars and some of the maxillary premolars. Based on the mandibular dental attrition stages proposed by Lovejoy (1985), TLB scores I, giving a minimum estimate of 45-55 years. This range is further corroborated by Brothwell's (1989) system, which gives a minimum of 50 years for TLB.

In the analysis of TLC- 1 , the lateral-anterior suture closure system was not used due to damage on the superior sphenotemporal suture, preventing an assessment of the degree of closure. Closure of vault sutures gave a mean age estimate of ca. 49 years (Meindl and Lovejoy, 1985, Table 6). All teeth on TLC-1 are erupted and display high levels of dental attrition. Using the dental attrition system in Lovejoy (1985), TLC-1 scores $\mathrm{H}$ in the maxillary dentition and $\mathrm{I}$ in the mandibular system, giving a minimum age range of 45-55. This range is further corroborated by using Brothwell's (1989) system, which gives a minimum of 45 years for TLC-1.

\subsection{Biological sex assessment}

The biological sex assessment for TLB was based on the sexual features that could be recorded in the fragmentary calvaria and mandible (Table 7 ). The short, small mastoid process $(-1)$ as well as only slightly delimited supraciliary arches $(-1)$, the prominent parietal eminences $(-2)$ and a rounded orbital form with a sharp border $(-1)$ are female characteristics (Walrath et al., 2004). However, an inclined frontal profile $(+1)$ and the thick and high zygomatic process of the temporal $(+1)$ are male characteristics. Using Walrath et al.'s (2004) sexualization index (SI), TLB scores -0.5 , possibly indicating a female (Table 7 ). Additionally, the 
Table 3

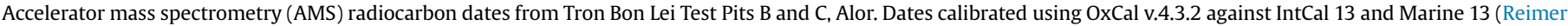
et al., 2013; Bronk Ramsey, 2017).

\begin{tabular}{|c|c|c|c|c|c|}
\hline Sample provenance & Sample type & Quality indicator ${ }^{\mathrm{a}}$ & SANU-number & Radiocarbon age (BP) & Calibrated age (cal BP, 95.4\% probability range) \\
\hline Test Pit B & Operculum of Turbo sp. & - & 42723 & $3275 \pm 20$ & $3560-3455$ \\
\hline Test Pit B & Shell of Barbatia sp. & - & 42724 & $3395 \pm 20$ & $3690-3585$ \\
\hline Test Pit B & Charcoal in situ & $54 \% \mathrm{C}$ & 41918 & $3065 \pm 20$ & $3350-3215$ \\
\hline Test Pit B & Shell; Saccostrea sp. & - & 42725 & $5010 \pm 20$ & $5440-5295$ \\
\hline Test Pit B & Charcoal in situ & $60 \% \mathrm{C}$ & 41919 & $3325 \pm 20$ & $3480-3610$ \\
\hline Test Pit B & Charcoal in situ & $60 \% C$ & 41920 & $3210 \pm 20$ & $3460-3380$ \\
\hline Test Pit B & Charcoal in situ & $60 \% C$ & 41921 & $3390 \pm 20$ & $3690-3580$ \\
\hline Test Pit B & Charcoal in situ & $63 \% \mathrm{C}$ & 43924 & $3350 \pm 25$ & $3680-3490$ \\
\hline Test Pit B & Charcoal in situ & $62 \% \mathrm{C}$ & 43925 & $3370 \pm 25$ & $3690-3560$ \\
\hline Test Pit B & Charcoal in situ & $62 \% \mathrm{C}$ & 43926 & $3680 \pm 25$ & $4090-3925$ \\
\hline Test Pit B & Charcoal in situ & $56 \% \mathrm{C}$ & 40123 & $6620 \pm 30$ & $7570-7440$ \\
\hline Test Pit B & Charcoal in situ & $61 \% \mathrm{C}$ & 43927 & $6845 \pm 30$ & $7740-7610$ \\
\hline Test Pit B & Charcoal in situ & $58 \% \mathrm{C}$ & 40121 & $7060 \pm 30$ & $7955-7840$ \\
\hline Test Pit B & Charcoal in situ & $48 \% \mathrm{C}$ & 40120 & $7205 \pm 30$ & $8150-7955$ \\
\hline Test Pit B & Charcoal in situ & $48 \% \mathrm{C}$ & 40039 & $7250 \pm 25$ & $8160-8005$ \\
\hline Test Pit B & Charcoal in situ & $54 \% \mathrm{C}$ & 39539 & $7355 \pm 35$ & $8305-8040$ \\
\hline Test Pit B & Charcoal in situ & $52 \% \mathrm{C}$ & 39538 & $8745 \pm 35$ & 9890-9560 \\
\hline Test Pit B & Charcoal in situ & $49 \% \mathrm{C}$ & 40118 & $8955 \pm 40$ & 10225-9920 \\
\hline Test Pit B & Shell of Haliotis asinina & - & 40128 & $9340 \pm 35$ & $10240-10110$ \\
\hline Test Pit B; Burial & Charcoal in situ & $57 \% \mathrm{C}$ & 40125 & $10140 \pm 45$ & $12030-11500$ \\
\hline Test Pit B; Burial & $\begin{array}{l}\text { Fish-hook made of a } \\
\text { Trochus niloticus shell }\end{array}$ & $<0.3 \%$ calcite & 41825 & $10230 \pm 30$ & $11300-11130$ \\
\hline Test Pit B; Burial & Charcoal in situ & $67 \% \mathrm{C}$ & 40124 & $10445 \pm 50$ & $12540-12120$ \\
\hline Test Pit B & Shell of Haliotis asinina & - & 40129 & $16210 \pm 60$ & $19235-18890$ \\
\hline Test Pit B & Shell of Nerita sp. & - & 40130 & $17630 \pm 70$ & $21000-20560$ \\
\hline Test Pit C & Operculum of Turbo sp. & - & 42726 & $6660 \pm 25$ & 7260-7135 \\
\hline Test Pit C & Charcoal in situ & $26 \% C$ & 40127 & $3610 \pm 25$ & $3845-3980$ \\
\hline Test Pit C & Charcoal in situ & $49 \% \mathrm{C}$ & 40126 & $3355 \pm 30$ & $3550-3650(78.6 \%)$ \\
\hline
\end{tabular}

a Charcoal should contain more than approximately 50\%C. \%C was measured volumetrically during cryogenic collection and purification. If calcite was present in the

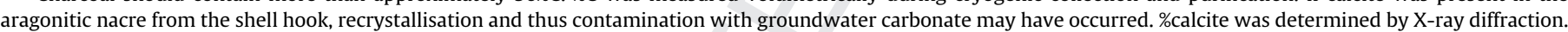

rounded profile of the mandibular corpus and the pointy but narrow chin point to a likely female (Bass, 1995). While the presence of mandibular ramus flexure could not be determined due to damage, the extant mandibular and cranial features are consistent in suggesting a likely female.

In the assessment of TLC-1, the glabella is large and prominent $(+2)$, the mastoids are long and large $(+2)$, the occipital crest is marked and nuchal lines are present $(+1)$, and the superciliary arches are robust and prominent $(+2)$. The external occipital protuberance is marked $(+1)$ and the zygomatics are reasonably high with an irregular surface $(+1)$, all of which are male characteristics (Walrath et al., 2004). Using Walrath et al.'s (2004) index, TLC-1 scores 1.23 , indicating a likely male (Table 7 ).

The mandible of TLC- 1 is fairly wide, flared and robust overall, exhibiting clear muscle markings in the gonial region, as well as large condyles (i.e., right condyle). The chin is quite square with a prominent mental eminence (Bass, 1995). Mandibular flexure is present at the level of teeth $(+1$; Loth and Henneberg, 1996). The mandibular and cranial features are thus consistent in indicating a likely male.

\subsection{Craniometric principal components analysis}

The PCA craniometric comparisons of the original measurements from the Pleistocene-Holocene specimens from Sunda, ISEA and Sahul identified two principal components (PC), whose loadings for the six analyzed measurements are listed in Table 8. As is common in biological applications of this statistical technique, PC1 (accounting for $89 \%$ of variance) corresponds to size (Joliffe, 2002). Accordingly, males, with their typically larger skulls, tend to score higher than their female counterparts (Fig. 5). However, even the males from the ISEA group (TLC-1, Hoekgrot, Liang Momer E, Melolo males) have a lower PC1 score than most of the Sahul females (e.g. Barham and Coobool Creek females), which epitomizes the typically small size of the ISEA specimens. The probably female Deep Skull from Niah yields a lower PC1 score than the Melolo males, but equivalent to or higher that the other ISEA specimens (male and female). As for PC2, which accounts for $10 \%$ of variance, it assigns a high score to broad crania with short cranial length and chords, and a low score to crania with the opposite shape (Table 8; Fig. 5). While there is substantial overlap between all three groups

Table 4

U-series isotopic and concentration data for the two human teeth from TLB and TLC-1, respectively ${ }^{\mathrm{a}}$.

\begin{tabular}{|c|c|c|c|c|c|c|c|c|c|}
\hline Skeleton & Lab code & $\mathrm{U}(\mathrm{ppm})$ & ${ }^{232} \mathrm{Th}(\mathrm{ppb})$ & $\left({ }^{230} \mathrm{Th} /{ }^{232} \mathrm{Th}\right)$ & $\left({ }^{230} \mathrm{Th} /{ }^{238} \mathrm{U}\right)$ & $\left({ }^{234} U /{ }^{238} U\right)$ & Uncorr. age (ka) & Corr. age (ka) & Corr. initial $\left({ }^{234} \mathrm{U} /{ }^{238} \mathrm{U}\right)$ \\
\hline TLB & LSQRB-A & $20.31 \pm 0.01$ & $11.70 \pm 0.04$ & $620 \pm 5$ & $0.1178 \pm 0.0007$ & $1.0459 \pm 0.0009$ & $13.02 \pm 0.09$ & $13.00 \pm 0.09$ & $1.048 \pm 0.001$ \\
\hline TLB & LSQRB-B & $20.74 \pm 0.01$ & $10.87 \pm 0.04$ & $687 \pm 4$ & $0.1185 \pm 0.0006$ & $1.0457 \pm 0.0007$ & $13.11 \pm 0.08$ & $13.09 \pm 0.08$ & $1.047 \pm 0.001$ \\
\hline TLB & LSQRB-C & $19.51 \pm 0.01$ & $22.33 \pm 0.07$ & $315 \pm 2$ & $0.1189 \pm 0.0005$ & $1.0471 \pm 0.0012$ & $13.13 \pm 0.06$ & $13.10 \pm 0.06$ & $1.049 \pm 0.001$ \\
\hline TLC-1 & TBC-C-A & $19.82 \pm 0.02$ & $64.24 \pm 0.13$ & $67 \pm 1$ & $0.0715 \pm 0.0006$ & $1.0232 \pm 0.0015$ & $7.89 \pm 0.07$ & $7.80 \pm 0.08$ & $1.024 \pm 0.002$ \\
\hline TLC-1 & TBC-C-B & $22.36 \pm 0.01$ & $85.62 \pm 0.14$ & $56 \pm 1$ & $0.0713 \pm 0.0007$ & $1.0256 \pm 0.0013$ & $7.85 \pm 0.08$ & $7.74 \pm 0.09$ & $1.026 \pm 0.001$ \\
\hline TLC-1 & TBC-C-C & $20.97 \pm 0.01$ & $85.91 \pm 0.16$ & $51.6 \pm 0.3$ & $0.0696 \pm 0.0004$ & $1.0218 \pm 0.0011$ & $7.69 \pm 0.04$ & $7.57 \pm 0.07$ & $1.022 \pm 0.001$ \\
\hline
\end{tabular}

a All ages reported to $2 \sigma$ error. Ratios in parentheses are activity ratios calculated from the atomic ratios, but normalized to measured values of secular-equilibrium HU- 1

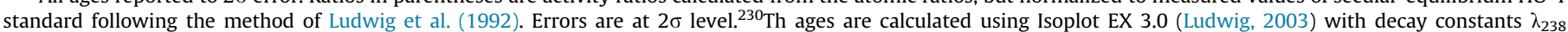

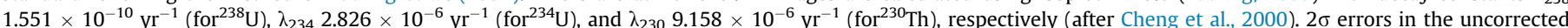

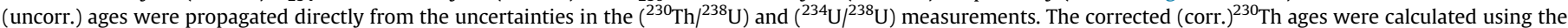
assumed bulk earth or upper crust value equivalent to the detrital ${ }^{230} \mathrm{Th} /{ }^{232} \mathrm{Th}$ activity ratio of 0.83 . 
Table 5

Detailed list of the cranial and postcranial remains documented in Tron Bon Lei (Alor Island).

\begin{tabular}{|c|c|c|}
\hline \multirow[t]{7}{*}{ TLB } & Cranium & $\begin{array}{l}\text { Frontal } \\
\text { Left and right parietals } \\
\text { Partial left temporal, preserving mastoid process and partial zygomatic } \\
\text { Partial right temporal, preserving mastoid process and partial zygomatic }\end{array}$ \\
\hline & Maxilla & $\begin{array}{l}\text { Left maxilla, preserving canine-third molar row } \\
\text { Right maxilla only preserves the frontal process of the zygomatic and the external side of the maxilla }\end{array}$ \\
\hline & Mandible & $\begin{array}{l}\text { Partially complete } \\
\text { Missing both condyles, right ramus, gonial angles and ventral part of right mandibular body }\end{array}$ \\
\hline & Cervical vertebrae & $\begin{array}{l}\text { Partial arch of the atlas and transverse forami } \\
2 \text { cervical vertebral bodies, highly fragmented }\end{array}$ \\
\hline & Rib & Fragments of rib bodies, highly fragmented \\
\hline & Scapulae & $\begin{array}{l}\text { Left scapula preserving partial glenoid cavity and spine } \\
\text { Right scapula preserving partial glenoid cavity, spine and body }\end{array}$ \\
\hline & Humerus & Fragment of diaphysis, missing both epiphyses. Not sided \\
\hline \multirow[t]{4}{*}{ TLC-1 } & Cranium & $\begin{array}{l}\text { Frontal } \\
\text { Left and right parietals } \\
\text { Complete right temporal } \\
\text { Partial left temporal, preserving partial zygomatic, mastoid process highly fragmented and petrous pyramid } \\
\text { Partial occipital, preserving most of the right side, external occipital protuberance and nuchal line. Missing foramen magnum and condyles }\end{array}$ \\
\hline & Mandible & Complete with dentition \\
\hline & Maxilla & $\begin{array}{l}\text { Left maxilla with complete dentition, frontal process, and partial palate. Complete left zygomatic } \\
\text { Right maxilla with complete dentition, isolated frontal process and partial palate. Complete right zygomatic }\end{array}$ \\
\hline & Postcranial & $\begin{array}{l}\text { Fragmentary vertebrae, ribs, carpals and foot phalanges } \\
\text { C1-C5 }\end{array}$ \\
\hline \multirow[t]{3}{*}{ TLC-2 } & Cranium & $\begin{array}{l}\text { Isolated vault fragments, likely to be part of the parietal } \\
\text { Complete right mastoid process }\end{array}$ \\
\hline & Mandible & Fragment of left mandibular body with $\mathrm{M}_{1}$ and $\mathrm{M}_{2}$ and mental foramen \\
\hline & Dentition & Three isolated upper molars \\
\hline \multirow[t]{2}{*}{ TLC-3 } & Humerus? & Diaphysis \\
\hline & Tibia? & Diaphysis \\
\hline
\end{tabular}

on this axis, it detects a generally broader cranial shape for the Sunda specimens compared with the similarly large Sahul crania.

When the modern reference material is added to this PCA (Fig. 6), PC1 (accounting for $86 \%$ of variance) is positively loaded for every measurement, with maximum cranial length (GOL) and maximum supraorbital breadth (MSB) yielding the highest scores (Table 8). Decrease in cranial size between the Late Pleistocene and recent times is suggested by the generally higher scores on PC1 for Sahul specimens compared to recent Australians, and for Sunda specimens compared to recent East Asians. While there is overlap in both cases, much of this can be explained by the generally smaller size of female compared with male skulls (e.g., the smaller PC1 score of the female Liang Lemdubu and Coobool Creek females

Table 6

Results for age-at-death estimation based on cranial suture scoring.

\begin{tabular}{lll}
\hline Cranial suture no. & \multicolumn{1}{c}{ TLB } & TLC-1 \\
\hline 1 & NA & 2 \\
2 & NA & 2 \\
3 & 1 & 3 \\
4 & 3 & 3 \\
5 & 3 & 3 \\
6 & 3 & 3 \\
7 & 3 & 3 \\
8 & NA & 0 \\
9 & NA & 2 \\
10 & NA & NA \\
$\Sigma$ degree $(1-7)$ & 13 & 19 \\
Average age & minimum 45 & ca. 48.8 \\
\hline
\end{tabular}

compared with Broadbeach males). PC2, which is heavily loaded on maximum cranial breadth (XCB), weakly discriminates between Sunda specimens (with relatively large $\mathrm{XCB}$ ) and Sahul specimens (with relatively small XCB), with and extensive overlap of the ISEA group with both the Sunda and Sahul groupings.

In this analysis, all of the non-ISEA groupings comprised of recent series overlap with ISEA, while the Australia and Papua New Guinea groupings also overlap with the Sunda grouping. TLC-1 emerges as typical of Papua New Guinea crania, whereas TLB lies close to female Japanese crania. Of particular importance, TLB has lower scores on PC1 than any of the Sunda and Sahul specimens, as does TLC-1, excluding the Niah Deep Skull which is renowned for its small size (Curnoe et al., 2016a). To some degree, the small size of

Table 7

Results for sex assessment for each of the features considered and sexualization index (SI).

\begin{tabular}{llc}
\hline & TLB & TLC-1 \\
\hline Glabella & -1 & +2 \\
Mastoid process & -1 & +2 \\
Nuchal plane & $\mathrm{NA}$ & +2 \\
Zygomatic process of the temporal & +1 & 0 \\
Supraciliary arches & -1 & +2 \\
Frontal and parietal eminences & -2 & -1 \\
External occipital protuberance & $\mathrm{NA}$ & +1 \\
Zygomatics & -1 & +1 \\
Frontal profile & +1 & +1 \\
Orbital form & -1 & +2 \\
SI $=(\Sigma$ score * weight $/ \Sigma$ weight $)$ & -0.5 & 1.23 \\
\hline
\end{tabular}


Table 8

Loadings of the variables for each principal component (PC), eigenvalue and percentage (\%) of variance obtained through both of the comparative methods applied.

\begin{tabular}{clcc}
\hline & & \multicolumn{2}{c}{ Original measurements } \\
\cline { 3 - 4 } & & PC1 & PC2 \\
\hline Cranial measurements & GOL & 0.75 & -0.44 \\
Pleistocene-Holocene & XCB & 0.41 & 0.87 \\
& FRC & 0.26 & -0.2 \\
& WMH & 0.01 & -0.11 \\
& PAC & 0.26 & 0.01 \\
& MSB & 0.35 & 0.07 \\
Cranial measurements & Eigenvalue & 170.69 & 20.77 \\
modern and prehistoric & \% variance & 89.15 & 10.85 \\
& GOL & 0.75 & -0.26 \\
& XCB & 0.15 & 0.94 \\
& FRC & 0.33 & 0.09 \\
& WMH & 0.07 & 0.18 \\
& PAC & 0.35 & -0.05 \\
& MSB & 0.42 & 0.06 \\
& Eigenvalue & 134.68 & 16.39 \\
& \% variance & 85.97 & 10.46 \\
\hline
\end{tabular}

Abbreviations: see Table 2.

TLB is exaggerated by the use of a proxy underestimate for cranial length. Although similarly small, the Deep Skull can be readily distinguished from the Tron Bon Lei crania by its broader cranial shape.

\section{Discussion}

\subsection{Age of remains}

Dates from three independent methods, U-Th, OSL (Table 4), and AMS ${ }^{14} \mathrm{C}$ (O'Connor et al., 2017b, Table 3 ) are all in broad agreement with each other. For the TLB remains, AMS ${ }^{14} \mathrm{C}$ dates from fishhooks associated with the burial (Table 3) are more or less consistent with U-Th ages from the skeleton itself, suggesting deposition around 11.5-13 ka, placing the TLB burial within the terminal Pleistocene.

No radiocarbon dates were obtained for any of the three bone accumulations in Test Pit C. AMS ${ }^{14} \mathrm{C}$ dates indicate occupations ranging to 3.5-7.2 ka cal $\mathrm{BP}$, although none of these samples were associated with the human remains and they were recovered from upper stratigraphic units: there is ca. $20 \mathrm{~cm}$ between the lowest dates (in terms of stratigraphic position) and the human remains. However, OSL dating of sediment sampled from the cranium suggests burial around $17.3 \pm 0.9 \mathrm{ka}$. Corresponding U-Th ages of tooth enamel are ca. $7.7 \mathrm{ka}$., but these represent minimum age estimates, suggesting delayed uptake of $U$ following burial. Both models of analysis used for OSL dating (CAM and FMM) yielded dates ca. 16-17 ka BP, with only a small portion of the grains dated producing younger dates. Collectively, these ages support an age of Late Pleistocene for the TLC-1 skeleton, but slightly older than the TLB remains.

\subsection{Implications for evolution and migration based on cranial measurements}

The craniometric comparison of the Tron Bon Lei remains with the crania recovered in surrounding geographic regions allow us to discuss some of the evolutionary models proposed for AMH in ISEA and the Wallacean Islands. The Tron Bon Lei crania are unique even by Pleistocene standards in the combination of small and narrow morphologies. They are smaller than any of the Pleistocene cranial remains reported from Sunda or Sahul, with the potential exception of the Deep Skull from Niah Cave. However, the broad morphology of the Deep Skull distinguishes it from Tron Bon Lei, notably the male TLC- 1 cranium, that has a narrower morphology than any of the other analyzed Pleistocene remains (apart from the enigmatic Cohuna fossil).

The small size of the Late Pleistocene individuals buried at Niah is also indicated by other human fossils from the site. Analysis of the partial femur associated with the Deep Skull suggests a stature

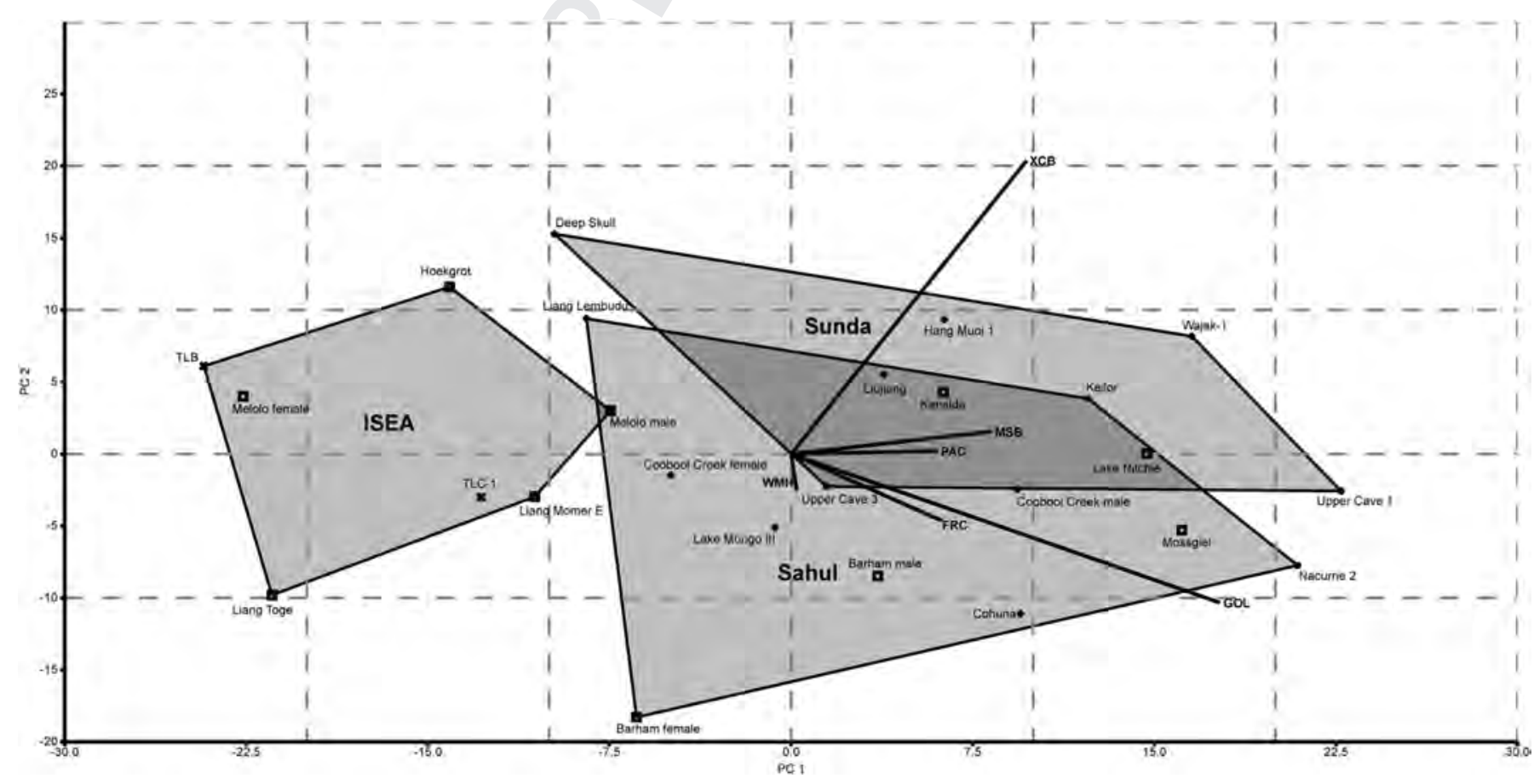

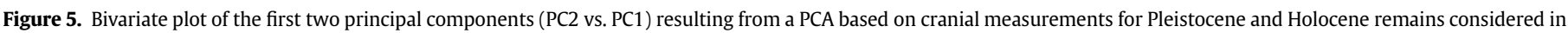
the analysis. Refer to Table 8 for variable loadings, eigenvalues and percentages of variance. 


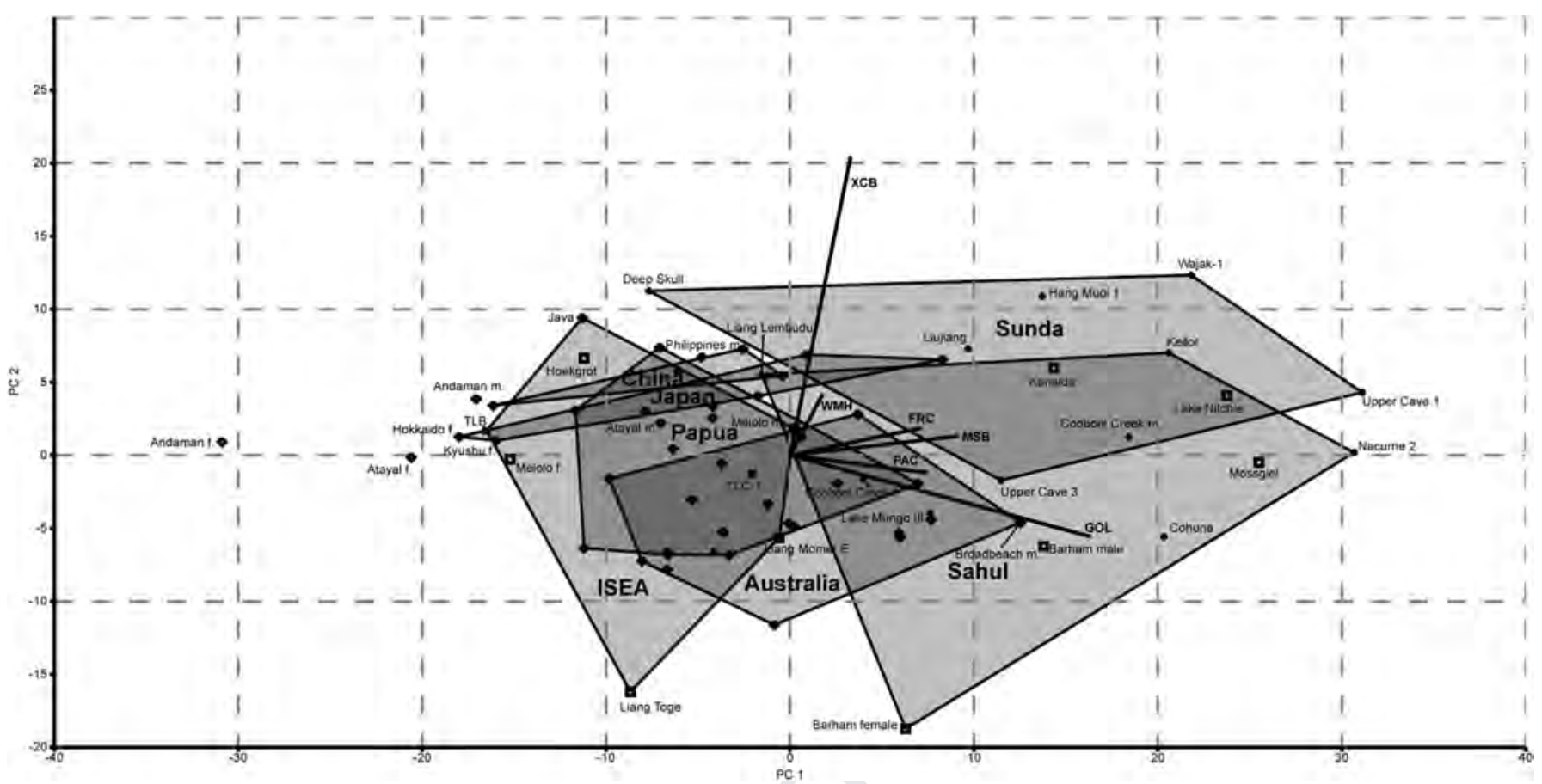

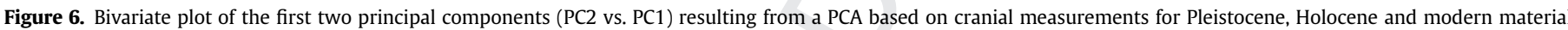
considered in this analysis. Refer to Table 8 for variable loadings, eigenvalues and percentages of variance. Abbreviations: $\mathrm{m}=$ male; $\mathrm{f}=$ female.

of around 145-146 cm and a body mass of around $35 \mathrm{~kg}$, smaller than recorded for any other Late Pleistocene AMH but fully in keeping with values recorded for recent ISEA Negritos (Curnoe et al., 2019). Three partial mandibles have recently been described from Niah Cave (Curnoe et al., 2018). The oldest specimen (E/B1 100"), with a U-series age of ca. 26-25 ka, is argued by Curnoe et al. (2018) to be unusually small and robust. The other highly fragmentary specimens are dated to a minimum of ca. $11-10.5 \mathrm{ka}$ and ca. $10-9 \mathrm{ka}$, respectively. The $11-10.5 \mathrm{ka}$ specimen (D/N5 $42-48$ ") is said to be larger than E/B1 100" and also robust. The youngest specimen is too fragmentary for the morphological data to be useful for assessing affinities. Although the small humans represented at Niah are considerably older than the similarly small individuals buried at Tron Bon Lei, they indicate that small body size fell within the range of phenotypic variability of Late Pleistocene Sunda shelf islanders and Island Southeast Asians.

As the only Pleistocene AMH fossil remains from the Lesser Sunda Islands, TLB and TLC-1 cannot be compared with other Pleistocene crania from nearby islands. However, the small size of the Tron Bon Lei remains show parallels with Holocene AMH remains from Flores, supporting the evolutionary and migratory model proposed by Van der Plas (2007) for the Wallacean Islands. Van der Plas identified the presence of a population in Wallacea yielding different cranial features than the Sunda and Sahul types described by Storm (1995), specifically characterized by a small cranial size. The remains from Tron Bon Lei conform with this distinct population complex in southeastern Indonesia, adding time depth to this model. The continuing distinctiveness of southeastern Indonesians from surrounding populations is exemplified by the Liang Toge cranium, which, with its extremely narrow cranial form, places it outside of the range of Sunda and Sahul specimens on PC1.

The trajectory of cultural change and population dispersal during the late Holocene was different in the Lesser Sunda Islands (including the northern Moluccas) compared with the islands to their north and their west. In the Lesser Sundas/northern Moluccas, both Austronesian and non-Austronesian languages are spoken today, and the oldest open sites with a rich material culture date to the Metal Phase, within the last 2000 years (Bellwood et al., 1998; O'Connor, 2015; Bellwood, 2017). In Sulawesi, the Philippines, and the Sunda shelf islands, in contrast, a much stronger imprint of Austronesian immigrants from Taiwan is indicated by the comprehensive spread of Austronesian languages and the documentation of numerous open sites with a rich 'Neolithic' material culture (pottery and polished stone artifacts) dating to between 4 and $2 \mathrm{ka}$. Nonetheless, across ISEA, cave sites with hunter-gatherer occupation on the eve of the Neolithic show continuity of the preNeolithic material culture, apart from the light presence of pottery and polished stone artifacts, reflecting exchange between resilient hunter-gatherer and Austronesian immigrant communities (Bulbeck, 2019). Neolithic skull shapes in the Sunda shelf islands and the Philippines vary between broad (for instance, Hoekgrot, this study) and elongated (Bulbeck, 2019), pointing to complex genetic exchange between the pre-Neolithic hunter-gatherers and the Austronesian immigrants. In the Lesser Sunda Islands, on the other hand, the small and narrow skull shape of the Tron Bon Lei, Liang Momer and Liang Toge crania persisted to the Metal Age, whether we consider the late Holocene remains from Liang Bua (Sukadana, 1981) or Melolo (this study).

How this evidence for population continuity in the Lesser Sunda Islands, between the Late Pleistocene and late Holocene, integrates with the archaeological and genetic evidence proposed to explain the wider peopling of ISEA remains open to debate. Sampling of TLB and TLC-1 for aDNA has been unsuccessful, a common trait in tropical samples due to poor preservation conditions (McColl et al., 03 2018).

Nevertheless, genomic research has a long tradition in ISEA (Cox, 2017). Analyses of genetic lineages in ISEA seem to reflect that the population history of ISEA is based on repeated and multiple population movements through from the Late Pleistocene, with some of the mtDNA 'founder' lineages beginning to diversify from the Neolithic (Cox, 2017). Sampling of modern mtDNA from 
populations in Alor corroborates the high genetic diversity of the modern communities in the east of the Lesser Sunda Islands (Tumonggor et al., 2013), as also supported by linguistic evidence. Pleistocene population movements are also supported by paternal DNA (Cox, 2017), with the variance in Y chromosome haplogroups suggesting a subdivision in the eastern and western islands of Southeast Asia, with a boundary running between Bali and Flores, corresponding roughly with Wallace's biogeographic boundary (Karafet et al., 2010). These authors suggested a four stage colonization model, with a first Late Pleistocene arrival of AMH (ca. 45-50 ka) into the region, followed by a second expansion after the LGM, a third stage corresponding to the Austronesian expansion, and a final stage with several incursions during historic times (Karafet et al., 2010). Genetic distances of the modern samples from Alor, used in their study, are closest to samples from other eastern Indonesian islands (Flores, Sumba, Lembata, Timor, and Moluccas), suggesting genetic continuity between the Lesser Sunda Islands but relative isolation from other islands in Wallacea and Sunda, consistent with our craniometric analysis. Likewise, analysis of the mitochondrial DNA of population from Timor-Leste indicates that genetic distances are smallest between Timor-Leste and the Lesser Sundas than they are to other island or mainland Southeast Asian groups (Gomes et al., 2015). Thus, the persistence of specific craniometrics in the Lesser Sunda Islands from the Pleistocene to the Metal Age is consistent with the relative (semi)isolation of the eastern Indonesian populations suggested by genetic studies (Karafet et al., 2010).

The earliest occupation from Tron Bon Lei is dated to ca. 21 and the rock shelter was occupied until ca. 18 ka cal BP (Samper Carro et al., 2017). The OSL dates for TLC -1 ( $17 \pm 0.9 \mathrm{ka} \mathrm{BP})$ leave open the possibility of occasional visits to the shelter ca. $17 \mathrm{ka}$. While the lack of defined occupational phases dated to that time may indicate that the site was used exclusively for burial, it may also be simply an outcome of limited sampling, as suggested for some of the occupational gaps in Timor-Leste sites (O'Connor et al., 2010). The next occupation phase in Tron Bon Lei dates to the terminal Pleistoceneearly Holocene (ca. 12.5-9.5 ka cal BP), associated with the TLB burial and corresponding to the post-LGM intensification of human occupation in ISEA (e.g., Rabett, 2012). Although separated by thousands of years, the persistence of the small cranial dimension from TLC-1 to TLB, distinctive from other Pleistocene specimens and similar to the oldest Holocene individuals from Flores, suggests these represent a single, somewhat isolated population on these islands during this time. This raises the possibility that the small cranial size observed could be the result of island dwarfing.

Island dwarfing has been observed for several large mammalian species evolving in relative isolation on islands (Van der Geer et al., 2011). The Lesser Sunda Islands commonly preserve fauna considered archetypical of this phenomenon. For example, members of the proboscidean genus Stegodon from Sumba, Flores, and Timor are much smaller than their mainland congenerics (Van den Bergh, 1999; Van der Geer et al., 2011; Louys et al., 2016). Dwarfing on islands is typically attributed to ecological release from predators or competitors as well as a response to limited resources on an island (e.g., Raia and Meiri, 2006; Bromham and Cardillo, 2007; Lomolino et al., 2013). The depauperate terrestrial fauna, in particular the lack of direct competitors and the limited number of large prey items, on the Wallacean islands might have led to extreme dwarfing in premodern hominins, who were largely dependent on terrestrial fauna to meet their protein requirements.

$H$. floresiensis has been suggested (Gordon et al., 2008) to be a product of insular dwarfing from Homo erectus. Additionally, Flores has been characterized as poor in resources for both Stegodon and $H$. floresiensis, with the energetic requirements outweighing the risk of predation by the co-habiting Komodo dragons (Dennell et al., 2014). The recently described Homo luzonesis, whose phylogenetic relationships within Homo are still unclear, also presents small dimensions that have been suggested as a potential effect of insular evolution, although further evidence would be needed to support this hypothesis (Détroit et al., 2019).

The recent genetic study by Tucci et al. (2018) of the Rampasasa 'pygmies' of highland Flores identified genetic mechanisms that positively selected for small stature, modulated through dietary restrictions. However, restrictions imposed by depauperate terrestrial faunal resources should have been ameliorated for coastal AMH on the islands who were able to take advantage of the rich and diverse marine foods found around the coastlines (Samper Carro et al., 2016, 2017; O'Connor et al., 2017a). That the populations on Alor had the ability and technology to exploit the rich marine resources is shown by the presence of fish-hooks and the vast icthyoarchaeological assemblages documented (Samper Carro et al., 2016, 2017; O'Connor et al., 2017b). Accordingly, the small size of the cranial remains may be due to selection pressures not related to resources depletion, but perhaps more likely associated with genetic isolation combined with predator release and lack of similar-sized competitors.

\section{Conclusions}

The new dates and analyses of the human remains documented in Tron Bon Lei (Alor, Indonesia) provide insights into human migration during the Pleistocene in the Wallacean Islands. Additionally, the complementary research conducted on other aspects of the archaeological context where the human remains were recovered, such as the zooarchaeological assemblages, raw materials, and grave goods, allow us to draw a more complete picture of the living and environmental context in the Lesser Sunda Islands from the Late Pleistocene to the Holocene (Samper Carro et al., 2016, 2017; O'Connor et al., 2017a,b; Hawkins et al., 2018).

The craniometrics recorded in the AMH remains from Tron Bon Lei suggest these individuals have a cranial morphology similar to populations documented in the middle and late Holocene in the region. The characteristics documented for TLB and TLC- 1 suggest these individuals may be representatives of a discrete gracile group living in ISEA from the Late Pleistocene, surviving into the Holocene. This is particularly hinted at by craniometric similarities with middle to late Holocene individuals from Flores and Sumba. Our results support the hypothesis of the evolution of a distinctive south-eastern Indonesian population by (at least) the terminal Pleistocene, which can be traced through to the middle to late Holocene individuals from the nearby island of Flores.

\section{Acknowledgments}

Fieldwork in Alor was funded by an ARC Laureate to S.OC (FL120100156), which was conducted under an Indonesian Foreign Research Permit (O'Connor 1304/FRP/SM/V/2014). We would like to thank the community of Lerabain, the students from Universitas Gadjah Mada, Yogyakarta, Stuart Hawkins and Putu Yuda from Balar Arkeologi Bali. We would like to thank David M. Alba, Tyler Faith and three anonymous reviewers for their useful comments that have greatly improved this manuscript.

\section{Supplementary Online Material}

Supplementary online material to this article can be found online at https://doi.org/10.1016/j.jhevol.2019.07.002. 


\section{Uncited reference}

Saini et al., 2017.

\section{References}

Aubert, M., Brumm, A., Ramli, M., Sutikna, T., Saptomo, E.W., Hakim, B. Morwood, M.J., van der Bergh, G.D., Kinsley, L., Dosseto, A., 2014. Pleistocene cave art from Sulawesi, Indonesia. Nature 514, 223-227.

Bae, C.J., Douka, K., Petraglia, M.D., 2017. On the origin of modern humans: Asian perspectives. Science 358, eaai9067.

Bass, W.M., 1995. Human osteology: A laboratory and field manual, $4^{\text {th }}$ ed. Missouri Archaeological Society, Columbia.

Bellwood, P., Nitihaminoto, G., Irwin, G., Gunadi, A.W., Tanudirjo, D., 1998. 35,000 years of prehistory in the northern Moluccas. In: Bartstra, G.J. (Ed.), Bird's Head approaches: Irian Jaya studies-a programme for interdisciplinary research. A.A. Balkema, Rotterdam, pp. 233-275.

Bellwood, P., 2017. First Islanders: Prehistory and Human Migration in Island Southeast Asia. John Wiley \& Sons, Hoboken.

Brandão, A., Eng, K.K., Rito, T., Cavadas, B., Bulbeck, D., Gandini, F., Pala, M., Mormina, M., Hudson, B., White, J., Ko, T.M., Saidin, M., Zafarina, Z., Oppenheimer, S., Richards, M.B., Pereira, L., Soares, P., 2016. Quantifying the legacy of the Chinese Neolithic on the maternal genetic heritage of Taiwan and Island Southeast Asia. Human Genetics 135, 363-376.

Bromham, L., Cardillo, M., 2007. Primates follow the 'island rule': implications for interpreting Homo floresiensis. Biology Letters 3, 398-400.

Bronk Ramsey, C., 2017. Methods for summarizing radiocarbon datasets. Radiocarbon 59, 1809-1833.

Brothwell, D.R., 1981. Digging Up Bones: The Excavation Treatment, and Study of Human Skeletal Remains. Cornell University Press, Ithaca.

Brothwell, D.R., 1989. The relationship of tooth wear to aging. In: İscan, M.Y. (Ed.), Age markers in the human skeleton. Charles C. Thomas Publisher Ltd, Springfield, Illinois, pp. 303-318.

Brown, P., 1989. Coobool Creek. Department of Prehistory, Research School of Pacific and Asian Studies, The Australian National University, Canberra.

Bulbeck, D., 2006. The last Glacial Maximum human burial from Liang Lembudu in northern Sahulland. In: O'Connor, S., Spriggs, M., Veth, P. (Eds.), The Archaeology of Aru Islands, Eastern Indonesia. ANU press, Canberra, pp. 255-294.

Bulbeck, D., Oxenham, M., Nguyen, L.C., Nguyen, K.T., 2007. Implications of the terminal Pleistocene skull from Hang Muoi, North Vietnam. Vietnam Archaeology 2, 42-52.

Bulbeck, D., 2015. Changes in human tooth-size and shape with the Neolithic transition in Indo-Malaysia. In: Behie, A.M., Oxenham, M.F. (Eds.), Taxonomic Tapestries: The Threads of Evolutionary, Behavioural and Conservation Research. ANU press, Canberra, pp. 183-214.

Bulbeck, D., 2019. Island Southeast Asia: Neolithic. In: Smith, C. (Ed.), Encyclopedia of global archaeology. Springer, Cham. https://doi.org/10.1007/978-3-31951726-1 866-2.

Capelli, C., Wilson, J.F., Richards, M., Stumpf, M.P.H., Gratrix, F., Oppenheimer, S., Underhill, P., Pascali, V.L., Ko, T.M., Goldstein, D.B., 2001. A predominantly indigenous paternal heritage for the Austronesian-speaking peoples of insular Southeast Asia and Oceania. The American Journal of Human Genetics 68, 432-443.

Cheng, H., Adkins, J., Edwards, R.L., Boyle, E.A., 2000. U-Th dating of deep-sea corals. Geochimica and Cosmochimica Acta 64, 2401-2416.

Chi, Z., Hung, H., 2010. The emergence of agriculture in southern China. Antiquity $84,11-25$

Cox, M., 2017. The genetic history of human populations in Island Southeast Asia during the Late Pleistocene and Holocene. In: Bellwood, P. (Ed.), First Islanders: Prehistory and Human Migration in Island Southeast Asia. John Wiley \& Sons, Hoboken, pp. 107-116.

Curnoe, D., Datan, I., Taçon, P.S.C., Ung, C.L.M., Sauffi, M.S., 2016. Deep Skull from Niah Cave and the Pleistocene peopling of Southeast Asia. Frontiers in Ecology and Evolution 4, 75.

Curnoe, D., Datan, I., Zhao, J.-X., Ung, C.L.M., Aubert, M., Sauffi, M.S., Mei, G.H., Mendoza, R., Taçon, P.S.C., 2018. Rare Late Pleistocene-early Holocene human mandibles from the Niah Caves (Sarawak, Borneo). PLoS One 13, e0196633.

Curnoe, D., Datan, I., Goh, H.M., Sauffi, M.S., 2019. Femur associated with the Deep Skull from the West Mouth of the Niah Caves (Sarawak, Malaysia). Journal of Human Evolution 127, 133-148.

Dennell, R.W., Louys, J., O'Regan, H.J., Wilkinson, D.M., 2014. The origins and persistence of Homo floresiensis on Flores: biogeographical and ecological perspectives. Quaternary Science Reviews 96, 98-107.

Détroit, F., Mijares, A.S., Corny, J., Daver, G., Zanolli, C., Dizon, E., Robles, E., Grün, R. Piper, P.J., 2019. A new species of Homo from the Late Pleistocene of the Philippines. Nature 568, 181-186.

Gomes, S.M., Bodner, M., Souto, L., Zimmermann, B., Huber, G., Strobl, C., Röck, A.W., Achilli, A., Olivieri, A., Torroni, A., Côrte-Real, F., Parson, W., 2015. Human settlement history between Sunda and Sahul: a focus on East Timor (Timor-Leste) and the Pleistocenic mtDNA diversity. BMC Genomics 16, 70

Gordon, A.D., Nevell, L., Wood, B., 2008. The Homo floresiensis cranium (LB1): Size, scaling, and early Homo affinities. Proceedings of the National Academy of Sciences USA 105, 4650-4655.
Green, M., 1990. Prehistoric cranial variation in Papua New Guinea. Ph.D. Dissertation, Australian National University.

Groucutt, H.S., Grün, R., Zalmout, I.A.S., Drake, N.A., Armitage, S.J., Candy, I., ClarkWilson, R., Louys, J., Breeze, P.S., Duval, M., Buck, L.T., Kivell, T.L., Pomeroy, E. Stephens, N.B., Stock, J.T., Stewart, M., Price, G.J., Kinsley, L., Sung, W.W. Alsharekh, A, Al-Omari, A., Zahir, M., Memesh, A.M., Abdulshakoor, A.J., AlMasari, A.M., Bahameem, A.A., Al Murayyi, K.M.S., Zahrani, B., Scerri, E.L., Petraglia, M.D., 2018. Homo sapiens in Arabia by 85,000 years ago. Nature Ecology \& Evolution 2, 800.

Grün, R., 1999. AGE99. Australian National University, Canberra

Hammer, Ø., Harper, D.A.T., Ryan, P.D., 2001. PAST: Paleontological statistics software package for education and data analysis. Palaeontologia Electronica 4, 4

Hammer, Ø., Harper, D.A.T., 2006. Palaeontological Data Analysis. Blackwell Publishing Ltd, Carlton.

Hawkins, S., Samper Carro, S.C., Louys, J., Aplin, K., O'Connor, S., Mahirta, 2018 Human palaeoecological interactions and owl roosting at Tron Bon Lei, Alor Island, eastern Indonesia. Journal of Island and Coastal Archaeology 13, 371-387.

Hershkovitz, I., Weber, G.W., Quam, R., Duval, M., Grün, R., Kinsley, L., Ayalon, A. Bar-Matthews, M. Valladas, $\mathrm{H}$., Mercier, N., Arsuaga, J.L. Martinón-Torres, M. Bermúdez de Castro, J.M., Fornai, C., Martín-Francés, L., Sarig, R., May, H. Krenn, V.A., Slon, V., Rodríguez, L., García, R., Lorenzo, C., Carretero, J.M. Frumkin, A., Shahack-Gros, R., Bar-Yosef Mayer, D.E., Cui, Y., Wu, X., Peled, N. Groman-Yaroslavski, I., Weissbrod, L., Yeshurun, R., Tsatskin, A., Zaidner, Y, Weinstein-Evron, M., 2018. The earliest modern humans outside Africa. Science 359, 456-459.

Howells, W.W., 1973. Cranial variation in man. In: Papers of the Peabody Museum of Archaeology and Ethnology. Cambridge, Massachusetts.

Howells, W.W., 1989. Skull shapes and the map. In: Papers of the Peabody Museum of Archaeology and Ethnology, Cambridge, Massachusetts.

Hudjashov, G., Karafet, T.M., Lawson, D.J., Downey, S., Savina, O., Sudoyo, H., Lansing, J.S. Hammer, M.F., Cox, M.P., 2017. Complex patterns of admixture across the Indonesian archipelago. Molecular Biological Evolution 34, 2439-2452.

Ilin, A., Raiko, T., 2010. Practical approaches to principal component analysis in the presence of missing values. Journal of Machine Learning Research 11, 1957-2000.

Jacob, T., 1967. Some problems pertaining to the racial history of the Indonesian region. Ph.D. Dissertation, University of Utrecht.

Joliffe, I.T., 2002. Principal Components Analysis, $2^{\text {nd }}$ ed. Springer, New York.

Jungers, W.L., Falsetti, A.B., Wall, C.E., 1995. Shape, relative size and sizeadjustments in morphometrics. Yearbook of Physical Anthropology 38, 137-161.

Karafet, T.M., Hallmark, B., Cox, M.P., Sudoyo, H., Downey, S., Lansing, J.S., Hammer, M.F., 2010. Major east-west division underlies Y chromosome stratification across Indonesia. Molecular Biology Evolution 27, 1833-1840.

Kealy, S., Louys, J., O'Connor, S., 2017. Reconstructing palaeogeography and interisland visibility in the Wallacean archipelago during the likely period of Sahu colonization, 65-45,000 years ago. Archaeological Prospection 24, 259-272.

Lambeck, K., Chappell, J., 2001. Sea level change through the last glacial cycle Science 292, 679-686.

Lambeck, K., Rouby, H., Purcell, A., Sun, Y., Sambridge, M., 2014. Sea level and global ice volumes from the Last Glacial Maximum to the Holocene. Proceedings of the National Academy of Sciences USA 111, 15296-15303.

Larnach, S.L., Macintosh, N.W.G., 1970. The Craniology of the Aborigines of Queensland. University of Sydney, Sydney.

Lomolino, M.V., van der Geer, A.A., Lyras, G.A., Palombo, M.R., Sax, D.F., Rozzi, R., 2013. Of mice and mammoths: generality and antiquity of the island rule. Journal of Biogeography 40, 1427-1439.

Louys, J., Price, G.J., O'Connor, S., 2016. Direct dating of Pleistocene stegodon from Timor Island, East Nusa Tenggara. PeerJ 4, e1788.

Louys, J., O'Connor, S., Mahirta, Higgins, P., Hawkins, S., Maloney, T., 2018. New genus and species of giant rat from Alor Island, Indonesia. Journal of Asia-Pacific Biodiversity 11, 503-510.

Loth, S.R., Henneberg, M., 1996. Mandibular ramus flexure: a new morphological indicator of sexual dimorphism in the human skeleton. American Journal of Physical Anthropology 99, 473-485.

Lovejoy, C.O., 1985. Dental wear in the Libben population: its functional pattern and role in the determination of skeletal age at death. American Journal of Physica Anthropology 68, 47-56.

Ludwig, K.R., 2003. Users Manual for Isoplot/Ex version 3.0: A Geochronologica Toolkit for Microsoft Excel. Berkeley Geochronology Center, Berkeley.

Ludwig, K.R., Simmons, K.R., Szabo, B.J., Winograd, I.J., Landwehr, J.M., Riggs, A.C. Hoffman, R.J., 1992. Mass-spectrometric ${ }^{230}{ }^{T h}-{ }^{234} U-{ }^{238} \mathrm{U}$ dating of the Devils Hole calcite vein. Science 258, 284-287.

Martinón-Torres, M., Wu, X., Bermúdez de Castro, J.M., Xiang, S., Liu, W., 2017. Homo sapiens in the eastern Asian Late Pleistocene. Current Anthropology 58, S434-S448.

Matsumura, H., Oxenham, M.F., 2014. Demographic transitions and migration in prehistoric East/Southeast Asia through the lens of nonmetric dental traits. American Journal of Physical Anthropology 155, 45-65.

Matsumura, H., Hung, H.-C., Cuong, N.L., Zhao, Y.-F., He, G., Chi, Z., 2017. Mid-Holocene hunter-gatherers 'Gaomiao' in Hunan, China: The first of the two-laye model in the population history of East/Southeast Asia. In: Piper, P.J., Matsumura, H., Bulbeck, D. (Eds.), New Perspectives in Southeast Asian and Pacific Prehistory. ANU press, Canberra, pp. 61-78. 
McColl, H., Racimo, F., Vinner, L., Demeter, F., Gakuhari, T., Moreno-Mayar, J.V., van Driem, G., Wilken, U.G., Seguin-Orlando, A., de la Fuente Castro, C., Wasef, S., Shoocongdej, R., Souksavatdy, V., Sayavongkhamdy, T., Saidin, M.M., Allentoft, M.E., Sato, T., Malaspinas, A.-S., Aghakhanian, F.A., Korneliussen, T., Prokaska, A., Margaryan, A., de Barros Damgaard, P., Kaewsutthi, S., Lertrit, P., Nguyen, T.H.M.,., Hung, H.-C., Tran, T.M., Truong, H.N., Nguyen, G.H., Shahidan, S., Wiradnyana, K., Matsumae, H., Shigehara, N., Yoneda, M., Ishida, H., Masuyama, T., Yamada, Y., Tajima, A., Shibata, H., Toyoda, A., Hanihara, T., Nakagome, S., Deviese, T., Bacon, A.-M., Duringer, P., Poche, J.-L., Shackelford, L., Patole-Edoumba, E., Nguyen, A.T., Bellina-Pryce, B., Galipaud, J.G., Kinaston, R., Buckley, H., Pottier, C., Rasmussen, S., Higham, T., Foley, R.A., Mirazón Lahr, M., Orlando, L., Sikora, M., Phipps, M.E., Oota, H., Higham, C., Lambert, D.M., Willserslev, E., 2018. The prehistoric peopling of Southeast Asia. Science 361, 88-92.

Meindl, R.S., Lovejoy, C.O., 1985. Ectocranial suture closure: a revised method for the determination of skeletal age at death based on the lateral-anterior sutures. American Journal of Physical Anthropology 68, 57-66.

O'Connor, S., 2015. Rethinking the Neolithic in Island Southeast Asia, with particular reference to the archaeology of Timor-Leste and Sulawesi. Archipel 90, 15-48.

O'Connor, S., Aplin, K., 2007. A matter of balance: An overview of Pleistocene occupation history and the impact of the Last Glacial Phase in East Timor and the Aru Islands, eastern Indonesia. Archaeology in Oceania 42, 82-90.

O'Connor, S., Bulbeck, D., 2014. Homo sapiens societies in Indonesia and Southeastern Asia. In: Cummings, V., Jordan, P., Zvelebil, M. (Eds.), The Oxford Handbook of the Archaeology and Anthropology of Hunter-Gatherers. Oxford University Press, Oxford, pp. 346-367.

O'Connor, S., Barham, A., Spriggs, M., Veth, P., Aplin, K., St Pierre, E., 2010. Cave archaeology and sampling issues in the tropics: a case study from Lene Hara Cave, a 42,000 year old occupation site in East Timor, Island Southeast Asia. Australian Archaeology 71, 29-40.

O'Connor, S., Louys, J., Kealy, S., Samper Carro, S.C., 2017a. Hominin dispersal and settlement east of Huxley's Line: the role of sea level changes, island size, and subsistence behavior. Current Anthropology 58, S567-S582.

O'Connor, S., Mahirta, Samper Carro, S.C., Hawkins, S., Kealy, S., Louys, J., Wood, R. 2017b. Fishing in life and death: Pleistocene fish-hooks from a burial context on Alor Island, Indonesia. Antiquity 91, 1451-1468.

Ousely, S.D., Jantz, R.L., 2005. FORDISC 3.0 Personal Computer Forensic Discriminant Functions. University of Tennessee, Knoxville.

Pietrusewsky, M., 2010. A multivariate analysis of measurements recorded in early and more modern crania from East Asia and Southeast Asia. Quaternary International 211, 42-54.

Pike, A.W.G., Hedges, R.E.M., Van calsteren, P., 2002. U-series dating of bone using the diffusion-adsorption model. Geochimica et Cosmochimica Acta 66 4273-4286.

Piper, P.J., 2016. Human cultural, technological and adaptative changes from the end of the Pleistocene to the mid-Holocene in Southeast Asia. In: Oxenham, M. Buckley, H.R. (Eds.), The Routledge Handbook of Bioarchaeology in Southeast Asia and the Pacific Islands. Routledge, New York, pp. 24-44.

Prescott, J.R., Hutton, J.T., 1994. Cosmic ray contribution to dose rates for luminescence and ESR dating: large depths and long-term variations. Radiation Measurements 23, 497-500.

Price, G.J., Feng, Y.-X., Zhao, J.-X., Webb, G.E., 2013. Direct U-Th dating of vertebrate fossils with minimum sampling destruction and application to museum specimens. Quaternary Geochronology 18, 1-8.

Rabett, R.J., 2012. Human adaptation in the Asian Palaeolithic. Hominid dispersal and behaviour during the Late Quaternary. Cambridge University Press, New York.

Raia, P., Meiri, S., 2006. The island rule in large mammals: paleontology meets ecology. Evolution 60, 1731-1742.

Reimer, P., Bard, E., Bayliss, A., Beck, J.W., Blackwell, P.G., Bronk Ramsey, C., Buck, C.E., Cheng, H., Edwards, R.L., Friedrich, M., Grootes, P.M., Guilderson, T.P. Haflidason, H., Hajdas, I., Hatté, C., Heaton, T.J., Hoffman, D.L., Hogg, A.G. Hughen, K.A., Kaiser, K.F., Kromer, B., Manning, S.W., Niu, M., Reimer, R.W. Richards, D.A., Scott, E.M., Southon, J.R., Staff, R.A., Turney, C.S.M., van der Plicht, J., 2013. IntCal13 and Marine13 radiocarbon age calibration curves 050,000 years cal BP. Radiocarbon 55, 1869-1887.

Reyes-Centeno, H., Ghirotto, S., Détroit, F., Grimaud-Hervé, D., Barbujani, G. Harvati, K., 2014. Genomic and cranial phenotype data support multiple modern human dispersals from Africa and a southern route into Asia. Proceedings of the National Academy of Sciences USA 111, 7248-7253.

Richards, L.C., Miller, S.L.J., 1991. Relationships between age and dental attrition in Australian aboriginals. American Journal of Physical Anthropology 84, 159-164.
Saini, V., Mehta, M., Saini, R., Shamal, S.N., Singh, T.B., Tripathi, S.K., 2017. Is north Indian population changing its craniofacial form? A study of secular trends in craniometric indices and its relation to sex and ancestry estimation. Forensic Science and Criminology 2(2), 1-14.

Samper Carro, S.C., O'Connor, S., Louys, J., Hawkins, S., Mahirta, 2016. Human maritime subsistence strategies in the Lesser Sunda Islands during the terminal Pleistocene-early Holocene: New evidence from Alor, Indonesia. Quaternary International 416, 64-79.

Samper Carro, S.C., Louys, J., O'Connor, S., 2017. Methodological considerations for icthyoarchaeology from the Tron Bon Lei sequence, Alor, Indonesia. Archaeological Research in Asia 12, 11-22.

Shen, G., Wang, W., Wang, Q., Zhao, J., Collerson, K., Zhou, C., Tobias, P.V., 2002. Useries dating of Liujiang hominid site in Guangxi, Southern China. Journal of Human Evolution 43, 817-829.

Sikora, M., 2017. A genomic view of the Pleistocene population history of Asia. Current Anthropology 58, S397-S405.

Stoneking, M., Krause, J., 2011. Learning about human population history from ancient and modern genomes. Nature Reviews Genetics 12, 603-614.

Storm, P., 1995. The evolutionary significance of the Wajak skulls. Scripta Geologica $110,1-247$.

Sukadana, A.A., 1981. Peninggalan manusia di Liang Bua dan hubungannya dengan penemuan di Lewoleba dan Melolo. Berkala Bioantropologi Indonesia 1, 53-72.

Sutikna, T., Tocheri, M.W., Morwood, M.J., Saptomo, E.W., Jatmiko, Awe, R.D. Wasisto, S., Westaway, K.E., Aubert, M., Li, B., Zhao, J.-X., Storey, M., Alloway, B.V., Morley, M.W., Meijer, H.J.M., van den Bergh, G.D., Grün, R., Dosseto, A., Brumm, A., Jungers, W.L., Roberts, R.G., 2016. Revised stratigraphy and chronology for Homo floresiensis at Liang Bua in Indonesia. Nature 532, 366.

Sutikna, T., Tocheri, M.W., Tyler Faith, J., Jatmiko, Awe, R.D., Meijer, H.J.M., Saptomo, E.W., Roberts, R.G., 2018. The spatio-temporal distribution of archaeological and faunal finds at Liang Bua (Flores, Indonesia) in light of the revised chronology of Homo floresiensis. Journal of Human Evolution 124, 52-74.

Tabbada, K.A., Trejaut, J., Loo, J.H., Chen, Y.M., Lin, M., Mirazón-Lahr, M., Kivisild, T., De Ungria, M.C.A., 2010. Philippine mitochondrial DNA diversity: a populated viaduct between Taiwan and Indonesia? Molecular Biology and Evolution 27, 21-31.

Tucci, S., Vohr, S.H., McCoy, R.C., Vernot, B., Robinson, M.R., Barbieri, C., Nelson, B.J., Fu, W., Purnomo, G.A., Sudoyo, H., Eichler, E.E., Barbujani, G., Visscher, P.M., Akey, J.M., Green, R.E., 2018. Evolutionary history and adaptation of a human pygmy population of Flores Island, Indonesia. Science 361, 511-516.

Tumonggor, M.K., Karafet, T.M., Hallmark, B., Lansing, J.S., Sudoyo, H., Hammer, M.F., Cox, M.P., 2013. The Indonesian archipelago: an ancient genetic highway linking Asia and the Pacific. Journal of Human Genetics 58, 165-173.

Turner, C.G.I.I., 1990. Major features of Sundadonty and Sinodonty, including suggestions about East Asian microevolution, population history and Late Pleistocene relationships with Australian Aboriginals. American Journal of Physical Anthropology 82, 295-317.

Van den Bergh, G.D., 1999. The Late Neogene elephantoid-bearing faunas of Indonesia and their palaeozoogeographic implications. Scripta Geologica 117, $1-419$.

Van der Geer, A., Lyras, G., De Vos, J., Dermitzakis, M., 2011. Evolution of island mammals: adaptation and extinction of placental mammals on islands. John Wiley \& Sons, London.

Van der Plas, M., 2007. A new model for the evolution of Homo sapiens from the Wallacean islands. PalArch's Journal of Vertebrate Palaeontology 1(1), 1-121.

Walrath, D.E. Turner, P., Brǔžek, J. 2004. Reliability test of the visual assessment of cranial traits for sex determination. American Journal of Physical Anthropology $125,132-137$.

Webb, S.G., 1989. The Willandra Lakes hominids. Department of Prehistory, Research School of Pacific Studies, Australian National University, Canberra.

Westaway, K.E., Louys, J., Awe, R.D., Morwood, M.J., Price, G.J., Zhao, J.X., Aubert, M., Joannes-Boyau, R., Smith, T.M., Skinner, M.M., Compton, T., Bailey, R.M., van den Bergh, G.D., de Vos, J., Pike, A.W.G., Stringer, C., Saptomo, E.W., Rizal, Y., Zaim, J., Santoso, W.D., Trihascaryo, A., Kinsley, L., Sulistyanto, B., 2017. An early modern human presence in Sumatra 73,000-63,000 years ago. Nature 548, 322-325.

White, T.D., Folkens, P.A., 2005. The Human Bone Manual. Elsevier Academic Press, Amsterdam.

Yokoyama, Y., Falguères, C., Sémah, F., Jacob, T., Grün, R., 2008. Gamma-ray spectrometric dating of late Homo erectus skulls from Ngandong and Sambungmacan, Central Java, Indonesia. Journal of Human Evolution 55, 274-277.

Zhou, H., Zhao, J., Qing, W., Feng, Y., Tang, J., 2011. Speleothem-derived Asian summer monsoon variations in Central China, 54-46 ka. Journal of Quaternary Science 26, 781-790. 